\title{
A NEW STEREOSPONDYLOMORPH, KORKONTERPETON KALNENSE GEN. ET SP. NOV., FROM THE LOWER PERMIAN OF THE CZECH KRKONOŠE PIEDMONT BASIN AND A REDESCRIPTION OF INTASUCHUS SILVICOLA FROM THE LOWER PERMIAN OF RUSSIA (TEMNOSPONDYLI, AMPHIBIA)
}

\author{
RALF WERNEBURG ${ }^{1}$, STANISLAV ŠTAMBERG ${ }^{2, *}$, JEAN-SÉBASTIEN STEYER ${ }^{3}$
}

\author{
${ }^{1}$ Naturhistorisches Museum Schloss Bertholdsburg Schleusingen, Burgstraße 6, D-98553 Schleusingen, Germany; \\ e-mail:werneburg@museum-schleusingen.de. \\ ${ }^{2}$ Museum of Eastern Bohemia in Hradec Králové, Eliščino nábřeží 465, 50001 Hradec Králové, the Czech Republic; \\ e-mail: s.stamberg@muzeumhk.cz. \\ ${ }^{3}$ Centre de Recherches en Paléontologie de Paris, CNRS-MNHN-SU, Muséum national d'Histoire naturelle, CP38, 8 rue Buffon, 75005 Paris, \\ France; e-mail: jean-sebastien.steyer@mnhn.fr. \\ ${ }^{*}$ corresponding author
}

Werneburg, R., Štamberg, S., Steyer, J.-S. (2020): A new stereospondylomorph, Korkonterpeton kalnense gen. et sp. nov., from lower Permian of the Czech Krkonoše Piedmont Basin and a redescription of Intasuchus silvicola from the lower Permian of Russia (Temnospondyli, Amphibia). - Fossil Imprint, 76(2): 217-242, Praha. ISSN 2533-4050 (print), ISSN 2533-4069 (on-line).

\begin{abstract}
A new temnospondyl, Korkonterpeton kalnense gen. et sp. nov., is described on the basis of an almost complete specimen from the lover Permian Prosečné Formation of the Czech Krkonoše Piedmont Basin. The exceptional preservation of the holotype allows a detailed description of the cranial and postcranial characters: Korkonterpeton kalnense gen. et sp. nov. is characterized by the presence of vomerine fangs located anteriorly to the posterior choana, much longer than wide tabulars - as long as the supratemporals, a deeply concave posterior margin of the skull table, extraordinarily elongated exoccipitals, anteriorly widened pterygoids and a parasphenoid cultriform process swollen at its mid-length. In order to clarify the relationship between this new taxon and Intasuchus silvicola Konzhukova, 1956 from the lower Permian (late Kungurian) of the Russian Inta Basin, the latter is also redescribed here: Intasuchus silvicola exhibits a lacrimal entering the septomaxilla, a widened jugal, a posterolaterally widened interpterygoid vacuity, a subtemporal window elongated anteriorly up to the anterior orbital region, an elongated basipterygoid ramus which is as long as the orbit width, a vomer with a parachoanal tooth row, and an ectopterygoid of about the same length as the palatine. The description of Korkonterpeton kalnense gen. et sp. nov. and the revision of Intasuchus silvicola complete our knowledge on the origin and evolution of early stereospondylomorph temnospondyls during the lower Permian.
\end{abstract}

Key words: Korkonterpeton kalnense gen. et sp. nov., Krkonoše Piedmont Basin, Bohemian Massif, lower Permian, Intasuchus silvicola, anatomy, relationships

Received: April 20, 2020 | Accepted: August 16, 2020 | Issued: December 30, 2020

\section{Introduction}

Temnospondyls represent a large group of fossil amphibians known by more than 300 species that exhibitawide stratigraphical occurrence ranging from the Carboniferous to the Cretaceous (e.g., Ruta and Benton 2008). Among this group, the stereospondyls became more diversified during the Mesozoic (e.g., Fortuny et al. 2016). Stem stereospondyls, traditionally called stereospondylomorphs, are however the subject of intense debate concerning their phylogeny (e.g., Eltink et al. 2019). For example, the interrelationships of the Permian stereospondylomorphs Sclerocephalus, Cheliderpeton, Glanochton and Intasuchus from Laurussia (these taxa are known from Germany, the Czech Republic, France and Russia) have not been resolved (Ruta and Benton 2008, Schoch and Witzmann 2009b, Eltink et al. 2019). This is despite the fact that many well-preserved stereospondylomorph specimens have been described in the last decades (Milner 1978, Boy 1988, 1993, Werneburg 1992, Gubin 1997, Werneburg and Steyer 2002, Witzmann 2006, Witzmann and Schoch 2006, Schoch and Witzmann 2009a, b, Klembara and Steyer 2012). Yet some taxa still need to be revised: this is the case of Intasuchus silvicola from the lower Permian of the Russian Inta Basin, originally described by Konzhukova (1953, 1955, 1956), which is redescribed here in detail. In 2014, during palaeontological 
exploration in the Czech Krkonoše Piedmont Basin, one of us (SŠ) found a new large temnospondyl skeleton near Arnultovice village in the lower Permian Prosečné Formation of the Krkonoše Piedmont Basin (Text-figs 1, 2). The specimen MEBHK - P 82447 was then prepared by SŠ. It is deposited in the palaeontological collection in the Museum of Eastern Bohemia, Hradec Králové, the Czech Republic. The specimen is exquisitely preserved and consists of skull roof (Text-figs 3-5), palate (Text-fig. 6), mandible (Textfig. 7) and many postcranial elements (Text-figs 8-11). The postcranial elements are disarticulated. Each postcranial element shows fine preservation of yellowish colour. The whole specimen lies on a calcareous claystone's slab of around $26 \mathrm{~cm} \times 56 \mathrm{~cm}$. The slab consists of four pieces: one piece, containing only the skull, has been prepared from below to render the ventral portion of the palate view accessible. Traditionally, the genera Cheliderpeton and Intasuchus are included in the family Intasuchidae (Schoch and Milner 2000, Werneburg and Steyer 2002, Eltink et al. 2019). The description of the new skeleton from the Krkonoše Piedmont Basin and revision of Intasuchus allow another possible scenario to be proposed regarding the interrelationship of these stereospondylomorphs. In order to more clearly understand the relationships between the newly described Korkonterpeton kalnense gen. et sp. nov. and other stereospondylomorphs, one taxon needed to be revised: Intasuchus silvicola from the Permian of Russia. Described in 1956, I. silvicola had indeed never been redescribed so far, a systematic revision was therefore necessary.

\section{Geological setting, age and material of Korkonterpeton kalnense gen. et sp. nov.}

The Krkonoše Piedmont Basin (the Czech Republic) is a significant upper Palaeozoic basin expanding across the north-eastern region of the Bohemian Massif in Czechia. It belongs to a system of intramontaneous basins which were formed in the early post-orogenic phase during the Westphalian and Saxonian times (Moscovian to Sakmarian; Martínek et al. 2006). The basin is filled by continental layers with a total thickness of 1,800 m, deposited during the upper Carboniferous (Westphalian D, Stephanian), lower Permian to Triassic. The lower Permian layers are represented by the Vrchlabí Formation (Asselian), Prosečné Formation (Asselian or Sakmarian; discussion see below) and Chotěvice Formation (Asselian - Sakmarian or Sakmarian - Artiniskian; Prouza and Tásler 2001, Opluštil et al. 2016, Schneider et al. 2020).

The new amphibian skeleton MEBHK - P 82447 comes from the Prosečné Formation, and more precisely from the lacustrine Kalná Lake sequence. The Kalná Lake covered an area of minimaly $60 \mathrm{~km}^{2}$ according to surface outcrops, but was most likely much larger. The sediments of the Kalná Lake form a $10 \mathrm{~m}$ to $20 \mathrm{~m}$ thick set of grey, varicoloured marlstones, claystones, siltstones and limestones (Blecha et al. 1999). They contain several fossiliferous layers which can be distinguished from each other by specific actinopterygian and amphibian associations (Štamberg 2012, 2014a, see below).

The type locality of Korkonterpeton kalnense gen. et sp. nov. near the village of Arnultovice (Text-fig. 1) belongs among the youngest fossiliferous horizons of the Kalná Lake (upper Kalná Horizon in the sense of Opluštil et al. 2016: fig. 8) in the upper part of the Prosečné Formation (Textfig. 2a). The village of Arnultovice (3 km north from the town Hostinné) with the outcrop Arnultovice 'Úvozová cesta $\mathrm{v}$ rokli na okraji lesa' ('Track in ravine on the edge of the forest'; coordinates $50^{\circ} 33^{\prime} 58.599^{\prime \prime} \mathrm{N}$; $15^{\circ} 43^{\prime} 18.873^{\prime \prime} \mathrm{E}$ ) exposes a $4 \mathrm{~m}$ thick set of sediments (Štamberg 2014b). The upper bed of the outcrop is a $40-50 \mathrm{~cm}$ thick massive and badly cleavable pinkish dolomitic limestone (Text-fig. $2 \mathrm{~b}$ ) with isolated scales of actinopterygians and coprolites. It represents nearshore-lake sediments. Below follows the main fossiliferous bed, a $90 \mathrm{~cm}$ thick pinkish laminated

\section{KRKONOŠE PIEDMONT BASIN}

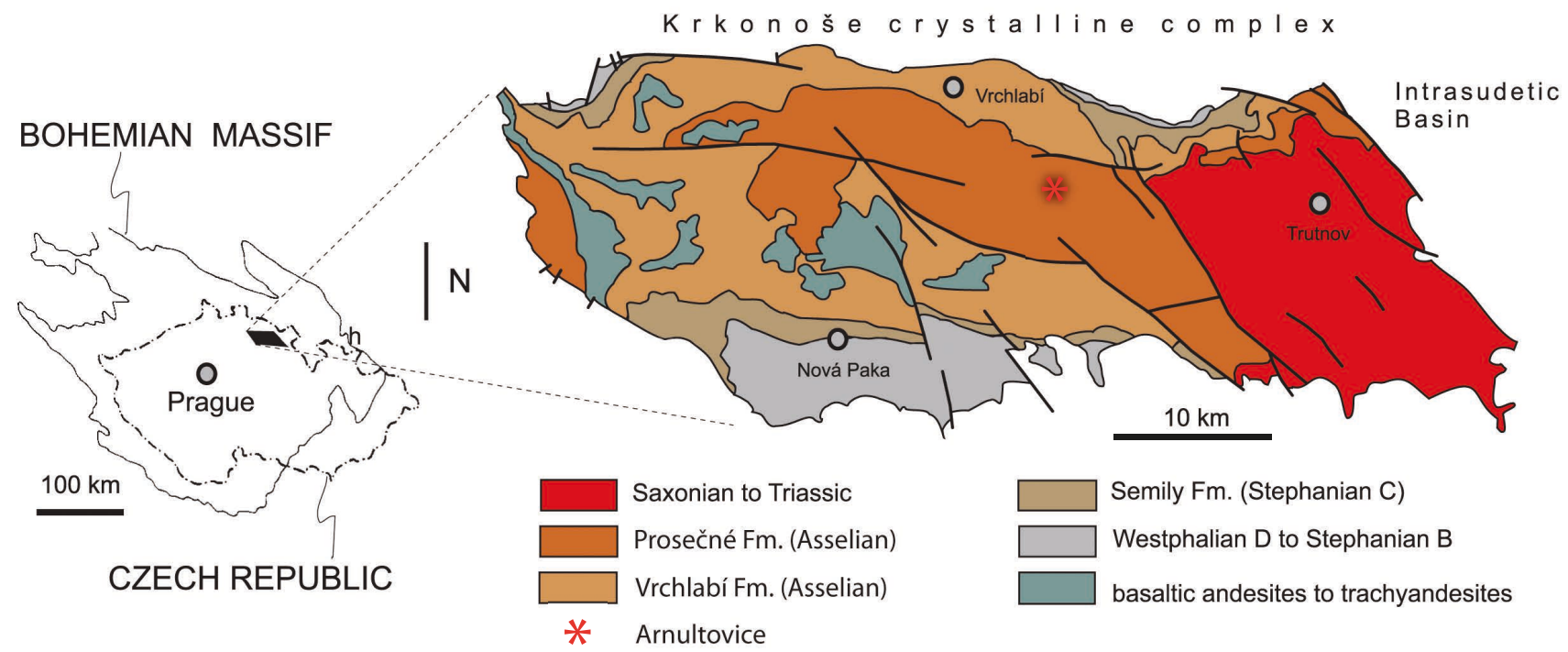

Text-fig. 1. Simplified geological map of the Krkonoše Piedmont Basin with position of the locality in Arnultovice (see asterisk; coordinates 50 $33^{\prime}$ 58.599" N; 15 $43^{\prime} 18.873^{\prime \prime}$ E). After Blecha et al. (1997). 


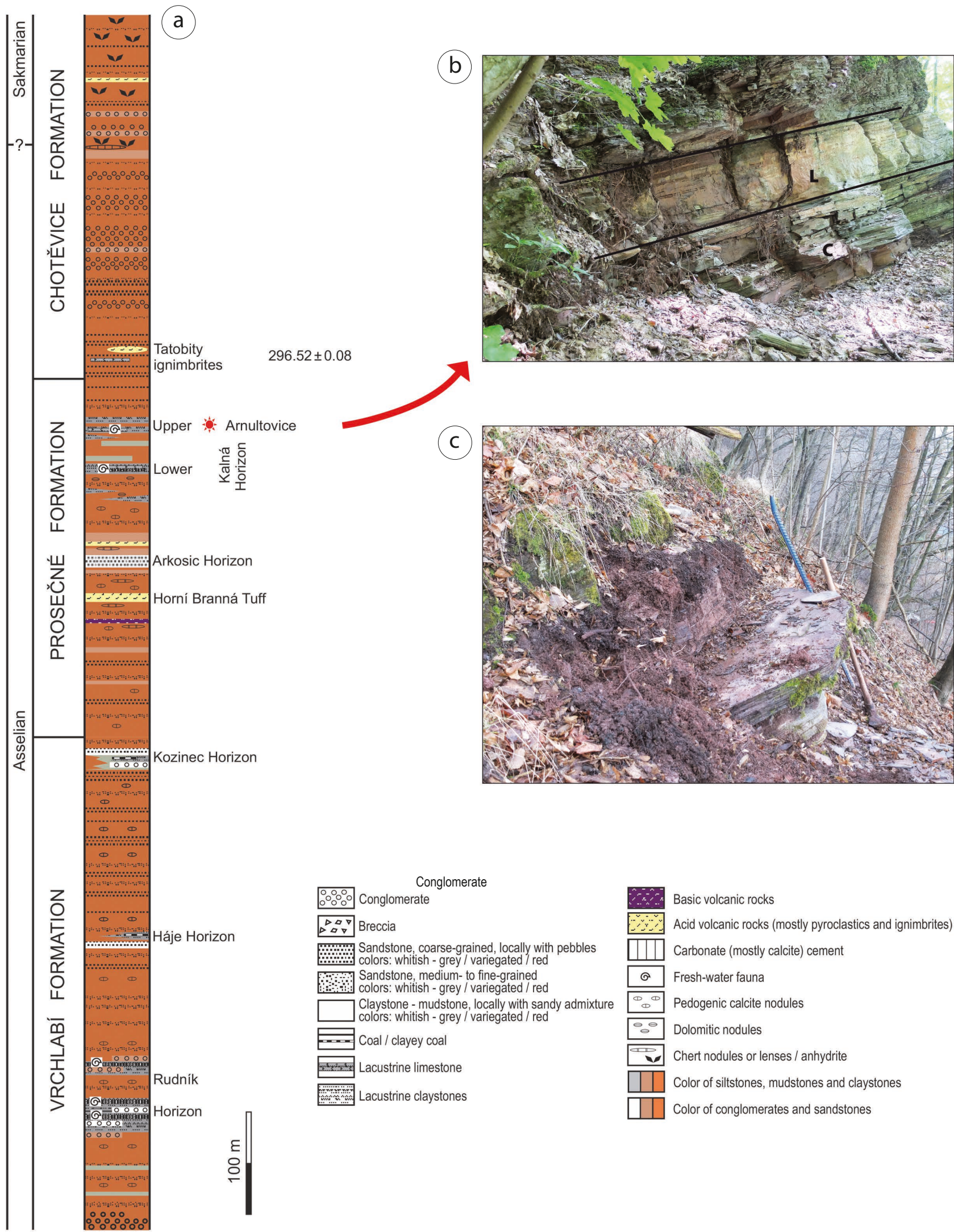

Text-fig. 2. Position of the finding locality Arnultovice 'Track in ravine on the edge of the forest' in the Permian stratigraphy of the Krkonoše Piedmont Basin. a: Idealised section of the Permian sediments of the Krkonoše Piedmont Basin. Locality Arnultovice and dating of overlying ignimrites in Tatobity are indicated. After Opluštil et al. (2016), based on data in Prouza and Tásler (2001), modified here. b: Detail of the outcrop 'Track in ravine on the edge of the forest' near Arnultovice with 40-50 cm thick massive badly cleavable pinkish dolomitic limestone ( $\mathrm{L}$ ) and laminated calcareous claystone $(\mathrm{C})$ with fauna. c: Artificial outcrop of laminated calcareous limestone in the continuation of the beds in forested slope $30 \mathrm{~m}$ northward from the main locality. 
calcareous claystone (Text-fig. 2b) which is the source of actinopterygians and the here described new amphibian. This bed is interpreted as an undisturbed quite-water offshore deposit in a semi-permanent lake (Blecha et al. 1999). The here described skeleton originates from an artificial outcrop (Text-fig. 2c) on a forested slope $30 \mathrm{~m}$ northward from the main locality. Below this bed follows a pinkish claystone with mudcracks but without any fauna or flora remain so far.

The pinkish laminated calcareous claystone bed contains actinopterygians of the families Amblypteridae (Paramblypterus zeidleri (FriTsCH, 1895) and Paramblypterus 'type B' sensu Štamberg 2014b) and Aeduellidae, a chondrichthyan spine of Xenacanthus sp., branchiosaurid amphibians, and the seymouriamorph Discosauriscus pulcherrimus (FRITSCH, 1879). This vertebrate association is similar to that of the Ruprechtice Horizon of the Olivětín Member, in the Intrasudetic Basin of Czechia, which includes the large stereospondylomorph Cheliderpeton vranyi FRIČ, 1877. This suggests that the here discussed upper Kalná Horizon and the Ruprechtice Horizon are equivalent in age. This age has recently been constrained by U-Pb CA-ID-TIMS radioisotopic datations of the Tatobity ignimbrite as $296.4 \pm 0.08 \mathrm{Ma}$ in the Chotervice Formation above the Prosečné Formation with the Kalná Horizon in the Krkonoše Piedmont Basin, and also the Vraní Hory rhyolites from the Nowa Ruda Member below the Olivětín Member of the Broumov Formation in the Intrasudetic Basin as $297.11 \pm 0.04 \mathrm{Ma}$ (Opluštil et al. 2016: fig. 12). Both ages correspond to the Asselian age according to the International Chronostratigraphic Chart 2020/03. However, Schneider and Werneburg (2012) and Schneider et al. (2020) interpreted the Ruprechtice Horizon according to different biostratigraphical scales (using amphibians and insects) to be of Sakmarian to Artinskian age. Their use of amphibian taxa as stratigraphical markers is still discussed (Steyer 2000a, 2004, Werneburg and Schneider 2004, 2006), but both biostratigraphical scales have been used in Europe and worldwide. These differences will have to be resolved in the future.

\section{Geological setting, age and material of Intasu- chus silvicola KonZhukova, 1956}

Intasuchus silvicola comes from a locality near the 'Greater Inta River' (hence its name) in the Komi Republic of northeastern European Russia. The material was discovered during the 1950s by prisoners working in a coal mine at a depth of 100 meters (Gubin, comm. pers. 1989). It is preserved in a grey bituminous sediment of the Intinskian Formation from the Ufimian, a Russian geological period that corresponds to the late Kungurian (Cisuralian, lower Permian) with a time range of 273-274 Ma (Schneider et al. 2020).

From this locality, Konzhukova (1956) described Intasuchus silvicola (see below only for the holotype PIN 570/1) and the probable eryopid Syndyodosuchus tetricus (PIN 570/2 and PIN 570/6) based on well-preserved and similar sized cranial specimens. Therefore, it was necessary to study the type material in detail (RW in 2012). Additionally, Konzhukova (1956) reported isolated postcranial material of, in our opinion, up to now 'uncertain affinity'.

\section{Methods}

Skeleton of the type specimen MEBHK - P 82447 was prepared mechanically by one of us (SŠ) using a Krantz pneumatic needle. Photographs were taken with a Nicon D5100 camera. Drawings were prepared with a 'camera lucida' at a Motic binocularin large size. Original fossil work was carried out for all parts of the type specimen. Comparison with other stereospondylomorph material is mainly based on personal observation of original specimens. Used dimensions of some bones are explained in figures.

\section{Institutional abbreviations}

$\begin{array}{ll}\text { MB } & \text { Museum für Naturkunde, Berlin, Germany } \\ \text { MEBHK - P } & \begin{array}{l}\text { Museum of Eastern Bohemia in Hradec } \\ \text { Králové, the Czech Republic }\end{array} \\ \text { PIN } & \begin{array}{l}\text { Paleontological Institute, Russian Academy of } \\ \text { Sciences, Moscow, Russia }\end{array}\end{array}$

\section{Systematic palaeontology}

\section{Order Temnospondyli ZiTTEL, 1888 \\ Suborder Stereospondylomorpha YATES et WARREN, 2000 Stereospondylomorpha incertae sedis}

\section{Genus Korkonterpeton gen. nov.}

Ty p e s pecies. Korkonterpeton kalnense sp. nov.

Etymology. After the Celtic name Korkontoi (Kоркóvтo1) for the Krkonoše Mountains, indicated by Ptolemais.

Diagnosis. Unique characters among stereospondylomorphs:

(1) Vomerine fangs anteriorly to the choana.

(2) Widened anterior region of the pterygoid clearly reaching the level of the posterior region of the choana.

(3) Exoccipital very elongated posteriorly.

Additional characters in contrast to a few stereospondylomorph genera, but shared with other ones:

(4) Elongated preorbital skull region measuring 2.42.5 times the length of the skull table (shared with Archegosaurus).

(5) Ventral premaxilla-maxilla-suture anteriorly to the choana (shared with Archegosaurus).

(6) Premaxillary snout region relatively wide $(\mathrm{aS} w /$ S1 > 0.33), box-like and blunt; with a moderately short premaxilla (shared with Glanochthon and Sclerocephalus).

(7) Posterolateral margin of the skull curved medially, with the maximal skull width at the level of the anterior extremity of the quadratojugal (shared with Intasuchus). (8) Small, sub-circular orbit (in large adults; shared with Cheliderpeton vranyi and Sclerocephalus).

(9) Relatively small teeth, of similar size on the ectopterygoid + palatine and maxilla + premaxilla, no large teeth on the ectopterygoid (shared with Archegosaurus).

(10) Ectopterygoid length twice that of the palatine (shared with Glanochthon). 
Remark. Although we only know one species of Korkonterpeton up to now, the diagnosis of the genus is proposed here based on the most significant differences when comparing this specimen with related genera. This diagnosis would be adapted by the possible discovery of other species.

\section{Korkonterpeton kalnense sp. nov.} Text-figs 3-11

Holotype. MEBHK - P 82447, a subcomplete skeleton corresponding to an adult individual (see below), and preserving a skull (length $15.7 \mathrm{~cm}$ ) in dorsal and ventral views, and well preserved but disarticulated postcranial elements.

Type horizon. Pinkish laminated claystone of the upper Kalná Horizon, upper part of Prosečné Formation (Asselian to Artinskian, lower Permian).

Type locality. Outcrop 'Track in ravine on the edge of the forest' (coordinates $50^{\circ} 33^{\prime} 58.599^{\prime \prime} \mathrm{N}$; $15^{\circ} 43^{\prime} 18.873^{\prime \prime}$ E) near the village of Arnultovice, $3 \mathrm{~km}$ north of the town Hostinné, Krkonoše Piedmont Basin, Bohemia, the Czech Republic.

Etymology. After the finding layer of the upper Kalná Horizon, named after the main fossil locality Horní Kalná, near Arnultovice.

D i a g n o s is . Stereospondylomorph with the following unique character combination:

(1) Tabular extremely elongated, as long as the supratemporal.

(2) Posteromedian skull margin extremely concave, with very distant posterior tabular corner $(\mathrm{Th} 1 / \mathrm{S} 1=0.14)$.

(3) Postparietal very short, half the length of that in related stereospondylomorphs.

(4) Posterior margin of the quadratojugal and dorsomedial quadrate concave, with a steplike shelf region.

(5) Cultriform process of the parasphenoid slightly swollen in its mid-region, its anterior third embedded in the posteromedian region of the vomer.

(6) Sphenethmoid and epipterygoid ossified early.

(7) Well-ossified, ventrally large hook-shaped quadrate, with an elongated anteromedial part.

Additional characters in contrast to those in Cheliderpeton vranyi, but shared with a few other stereospondylomorph temnospondyls:

(8) Elongated alary process of the premaxilla reaching the posterior level of the septomaxilla (shared with Intasuchus and Sclerocephalus).

(9) Maxilla laterally straight, with a small lateral excursion of its margin for an enlarged tooth (shared partly with Glanochthon latirostris).

(10) Long suture of the maxilla with the nasal and the septomaxilla, same length as the orbit width (shared with G. angusta).

(11) Lacrimal narrower than the alary process of the maxilla (similar with Sclerocephalus).

(12) Postorbital skull table relatively short $(\mathrm{H1} / \mathrm{S} 1=0.26$; shared with Glanochthon and Intasuchus).

(13) 'Otic notch' (squamosal embayment) reaching the level of the posterior margin of the supratemporal (shared with G. angusta).
Additional characters in contrast to those in a few stereospondylomorph species, but shared with others:

(14) Posterior quadratojugal enclosing the posterior part of the squamosal (may be similar in $C$. vranyi and Intasuchus).

(15) Dorsal part of the quadrate forming a narrow anteromedial directed bony-strip with a posterior process-like boss as the most posterior part of the skull (shared with archegosaurids and eryopids).

(16) Posterior process of the vomer very elongated almost up to the level of the posterior region of the palatine (similar in Glanochthon).

(17) Ectopterygoid posteriorly wide (shared with Archegosaurus).

(18) Pterygoid with very short basipterygoid (shared with Glanochthon and Archegosaurus).

(19) Anterior palatine ramus of the pterygoid medially curved (shared with Archegosaurus and Intasuchus).

(20) Transversal process of the pterygoid laterally swollen (similar in Glanochthon and Sclerocephalus).

(21) Basal plate of the parasphenoid short (similar in Glanochthon and Sclerocephalus).

(22) Anterior tip of the parasphenoid cultriform process reaching the level of the anterior portion of the pterygoid (shared with Archegosaurus and Intasuchus).

(23) Basipterygoid process of the basal plate anterolaterally directed and sutured with the basipterygoid process of the pterygoid (similar in Intasuchus).

(24) basal plate ventrally smooth (shared with Glanochthon and Sclerocephalus).

Description. Preservation. The skeleton of Korkonterpeton kalnense gen. et sp. nov. is well preserved and has been fully prepared: its skull is large (compared to the size of the postcranial elements) and visible in dorsal and palatal views. The hemimandibles are also visible from both sides, labially and lingually. The postcranial skeleton is disarticulated but with well-preserved elements including the vertebral column (with the atlas) and ribs.

Growth stage. The skull has a midline length of $15.7 \mathrm{~cm}$, and shows clear dermal ornamentation consisting of large sub-circular polygons in growth zones, turning into well-marked ridges and grooves, towards the periphery of the bones. The endocranium is also well ossified (see below). Together with the fact that the ribs present uncinate processes and the vertebrae transverse processes (see also description below), this indicates that MEBHK - P 82447 corresponds to an adult individual (Steyer 2000b).

Skull roof (Text-figs 3-5, 14, Tab. 1). The skull is subtriangular in outline, with a very elongated preorbital region (2.45 times the skull table length; Tab. $1: \mathrm{PO} / \mathrm{Hl}=2.45 ; \mathrm{PO} /$ $\mathrm{S} 1=0.60)$ and a short postorbital skull table $(\mathrm{H} 1 / \mathrm{S} 1=0.26)$, in contrast to $C$. vranyi. The tip of the snout is relatively wide $(\mathrm{aSw} / \mathrm{Sl}=0.35)$, box-like and blunt, as in Glanochthon (Schoch and Witzmann 2009b) and Sclerocephalus (Boy 1988, Schoch and Witzmann 2009a). The intranarial distance $\left(\mathrm{INw}_{\mathrm{w}} / \mathrm{Sl}=0.19\right)$ is longer than the intraorbital $\left(\mathrm{IOw}_{\mathrm{w}} /\right.$ $\mathrm{S} 1=0.17)$. The premaxilla is relatively short medially but it presents posteriorly a very elongated alary process that goes beyond the posterior margin of the external nostril. The septomaxilla is visible dorsally, but its dorsal contribution is 



Text-fig. 3. The dorsal skull roof of Korkonterpeton kalnense gen. et sp. nov. in dorsal view, holotype MEBHK - P 82447. a: drawing with ornamentation; b: drawing with ornamentation omitted; c: tentative reconstruction; d: holotype. Abbreviations: eo - exoccipital, f - frontal, fpq - paraquadrate foramen, ifc.pt - postorbital part of the infraorbital sulcus, ifc.sb - suborbital part of the infraorbital sulcus, ior - intraorbital ridges, $\mathbf{j}$ - jugal, $\mathbf{l}$ - lacrimal, $\mathbf{m}$ - maxilla, $\mathbf{n}$ - nasal, ol - occipital lamella, $\mathbf{p}$ - parietal, 


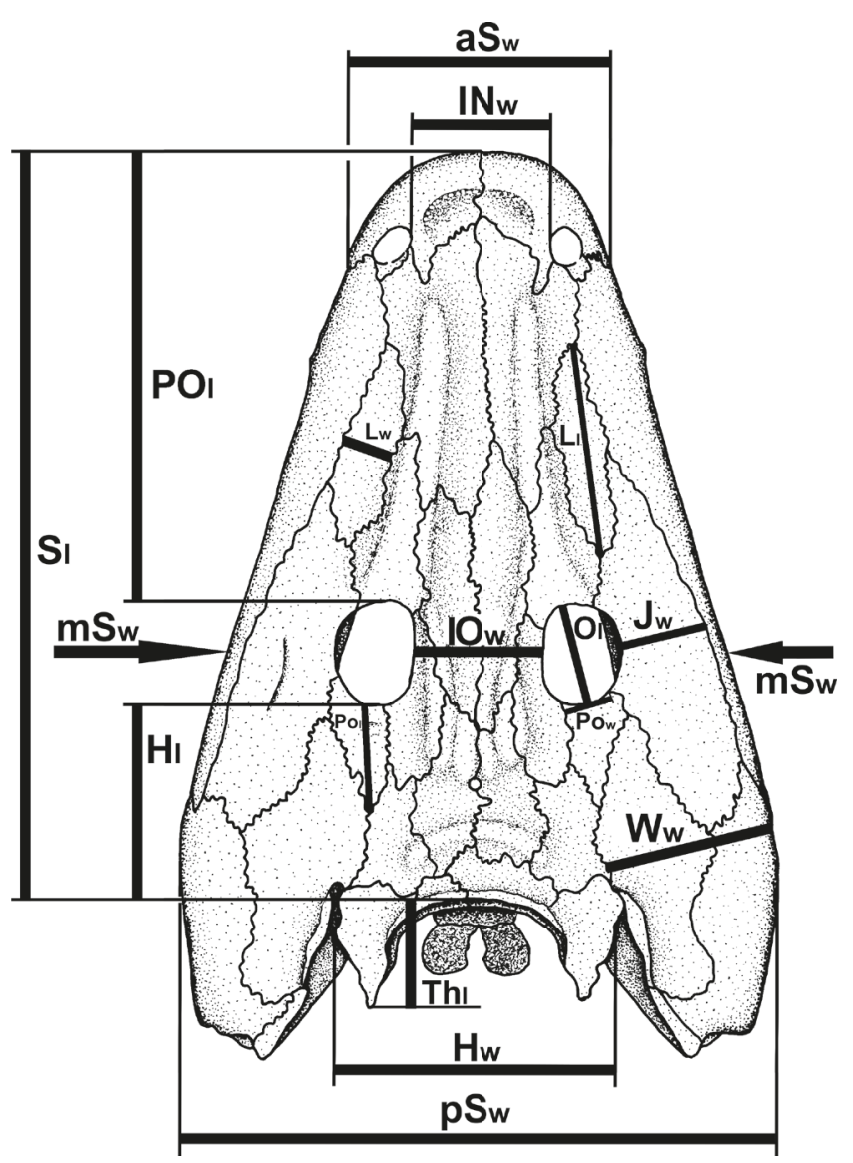

Text-fig. 4. Biometric measured distances on the dorsal skull roof of Korkonterpeton kalnense gen. et sp. nov., compare Table 1. Measurement abbreviations: aSw - anterior width of skull at level of maxilla-premaxilla sutures, $\mathrm{HI}$ - postorbital midline length of skull from level of posterior margins of orbits, $\mathrm{H}_{\mathrm{w}}$ - postorbital width of skull between lateral margins of supratemporals, $\mathrm{IN}_{\mathbf{w}}$ - minimum intranarial width, IOw minimum interorbital width, $\mathrm{Jw}_{\mathrm{w}}$ - transverse width of jugal at maximum lateral lacrimal extent of orbit, $\mathrm{LI}$ - maximum length of lacrimal, $L_{w}$ - maximum transverse width of lacrimal, $\mathrm{mS}_{\mathrm{w}}$ - midlength width of skull at midlength level of orbits, $\mathrm{Ol}$ - maximum length of orbit, $\mathrm{POI}$ - preorbital midline length of skull from level of anterior margins of orbits, Pol maximum posterior length of postorbital from posteriormost extent of orbit, Pow - maximum transverse width of postorbital at contribution to orbital margin, $\mathrm{pS}_{\mathrm{w}}$ - maximum posterior width of skull at level of posterolateral margins of cheeks, $\mathrm{Sl}$ - midline skull length, Thl - length of tabular horn between levels of posterior tabular corner and occipital midline margin, $W_{w}$ - maximum transverse width of cheek from lateral margin of supratemporal anterior to otic notch.

very small. The lateral margin of the skull roof, bordered by the maxilla, is very straight except at the level of the anterior tip of the lacrimal where the maxilla presents a small lateral expansion to accommodate a large tooth. This is sometimes the case in Glanochthon (Schoch and Witzmann 2009b: fig. 2). In Korkonterpeton kalnense gen. et sp. nov., the maxilla is elongated and posterodorsally reaches the quadratojugal. Its suture with the nasal is relatively long, as in Glanochthon angusta (Schoch and Witzmann 2009b). The lacrimal is relatively narrow and does not make contact with the nostril nor the orbit. The nasal is anteriorly widened and anteriorly extends to the anterior margin of the naris (in contrast to Intasuchus). The intraorbital region ( $\mathrm{IOw}_{\mathrm{w}}$ $\mathrm{S} 1=0.17)$ and the frontal are narrow. The orbits are subcircular and relatively small compared to the skull size $(\mathrm{Ol} /$ $\mathrm{S} 1=0.14)$. The prefrontal is anteriorly narrow and very elongated: it contacts the lacrimal in its anterior half. The jugal is relatively narrow, in contrast to Intasuchus.

The maximum width of the skull roof is at the level of the anterior portion of the quadratojugal $\left(\mathrm{pSw}_{\mathrm{w}} / \mathrm{S} 1=0.79\right)$, as in Intasuchus but in contrast to Glanochthon and Cheliderpeton vranyi (Werneburg and Steyer 2002). The quadrate is visible dorsally: its small dorsal contribution lies posterolateraly to the otic notch, and it contacts the quadratojugal laterally, the descendent lamina of the squamosal anteriorly, and the vertical pterygoid wall medially (Text-fig. 5a). The posterodorsal portion of the quadrate forms the quadrate boss. This boss is also visible in the archegosauroids Platyoposaurus stuckenbergi (PIN 3968/1; RW pers. obs.), Melosaurus uralensis (MB.Am.334a; RW pers. obs.), Kashmirosaurus ornatus (Werneburg and Schneider 1996: fig. 2F) and in the eryopid Clamorosaurus borealis (PIN 3950/1; RW pers. obs. and Gubin 1983: 114). In Korkonterpeton kalnense gen. et sp. nov., the quadrate boss, together with the posterodorsal portion of the quadratojugal, borders a very deep and concave condyle region of the skull roof. This region is so deep that the paraquadrate foramen is partly visible dorsally (Text-fig. 5a), as in the aquatic eryopid Glaukerpeton (Text-fig. 5b and Werneburg and Berman 2012). This condyle region is also significantly posterior to the occiput.

The postorbital is narrow and elongated, extending more posteriorly than the postfrontal. The postfrontal anteriorly contacts the prefrontal. Its posterior extremity reaches the level of the pineal foramen. The parietal and supratemporal are relatively narrow and elongated, but the supratemporal is slightly shorter than that of Glanochthon or C. vranyi. In Korkonterpeton kalnense gen. et sp. nov., this supratemporal does not contribute to the otic notch, as in Glanochthon angusta but not Intasuchus silvicola.

The postparietal is very short. The tabular is very elongated (as long as the supratemporal). The posterior margin of the skull table is extremely concave $(\mathrm{Th} 1 / \mathrm{S} 1=0.14)$. These characters were unknown within stereospondylomorphs so far.

The dorsal skull roof shows an interesting strutting pattern composed of distinct ridges (Text-fig. 3): the prefrontal ridge (prr, Text-fig. 3b), the most developed, is longitudinal. It starts narrowly at the level of the premaxillar alary process and runs along the nasal and prefrontal where it widens posteriorly. This ridge is known in many temnospondyls (e.g., Sawin 1941,

pm - premaxilla, po - postorbital, pp - postparietal, prf - prefrontal, prr - prefrontal ridge, psr - parietal-supratemporal ridge, pt - pterygoid, ptf - postfrontal, q - quadrate, q.j - quadratojugal, sm - septomaxilla, sq - squamosal, st - supratemporal, $t$ - tabular. $\mathrm{Sl}$ - midline skull length. 


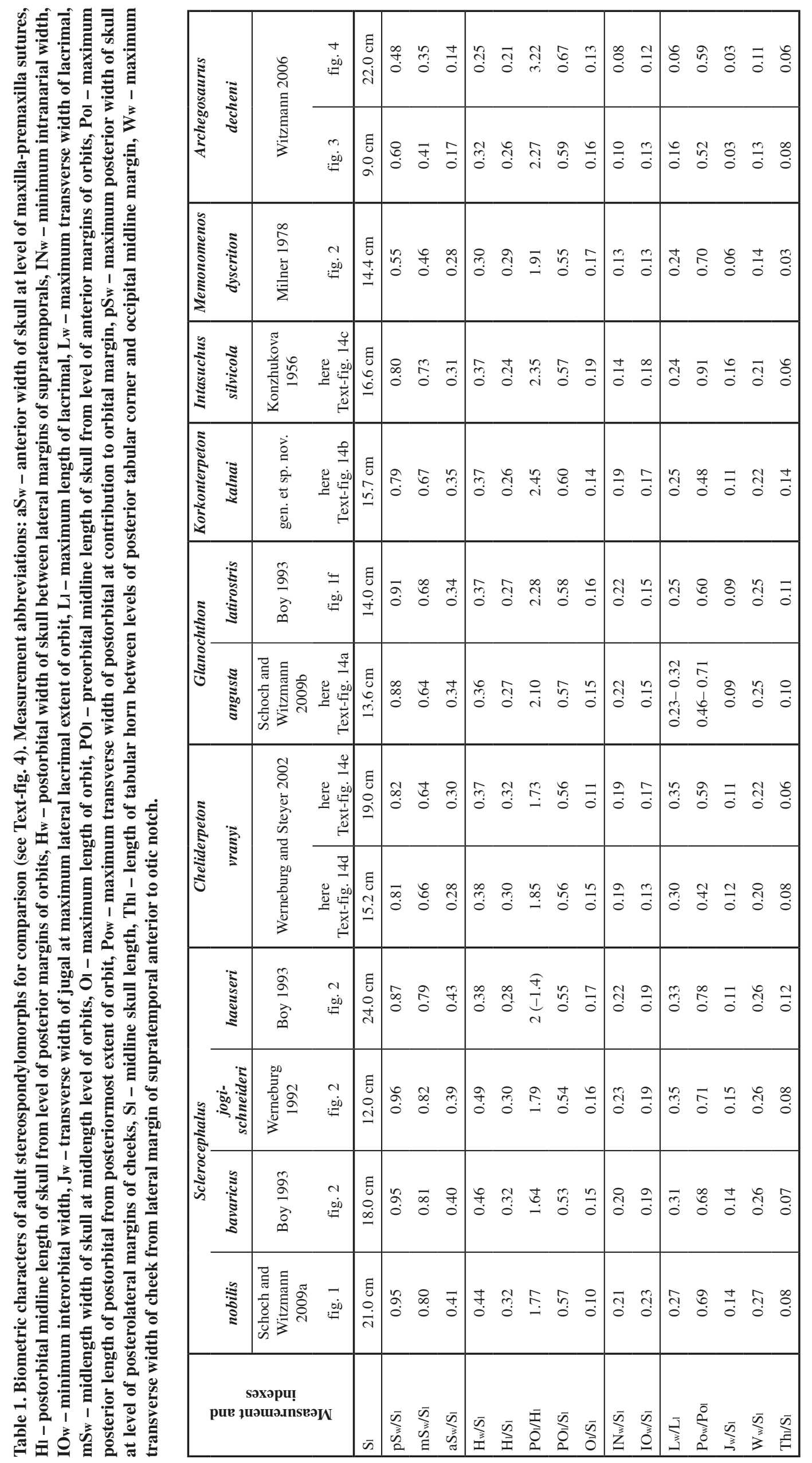



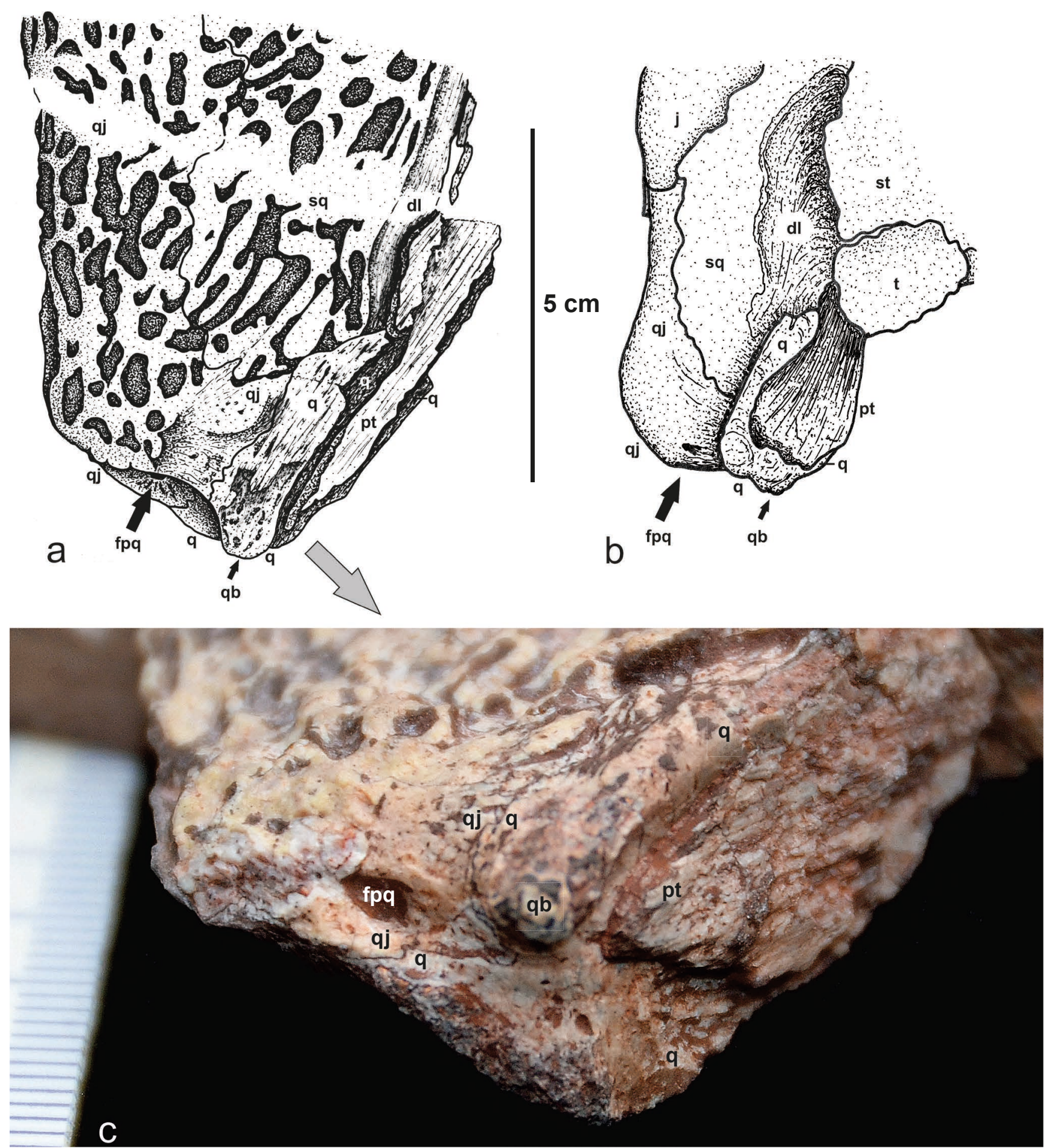

Text-fig. 5. The dorsal quadrate condyle region of the stereospondylomorph Korkonterpeton kalnense gen. et sp. nov. (a, c), and of the eryopid Glaukerpeton avinoffi RoMer, 1952 (b; after Werneburg and Berman 2012). Abbreviations: dl - lamina descendens of squamosal, fpq - paraquadrate foramen, $\mathbf{j}$ - jugal, pt - pterygoid, q - quadrate, qb - quadrate boss, qj - quadratojugal, sq squamosal, st - supratemporal, $\mathrm{t}$ - tabular.

Boy 1993, Werneburg 2007, Werneburg and Berman 2012). The intraorbital ridge (ior, Text-fig. 3b) is also longitudinal. It starts at the level of the pre- and postfrontal suture, runs along the suture between the frontal, the pre-and postfrontal, and ends posteriorly on the anterior part of the parietal, as in C. vranyi (Text-fig. 14e), but in contrast to Glanochthon latirostris (Schoch and Witzmann 2009b: fig. 4B). It is not clear if it is a continuation of the prefrontal ridge. The parietal-supratemporal ridge (psr, Text-fig. 3b) is transversal: it runs anteriorly along the parietal-postparietal suture and laterally reaches the supratemporal, as in Intasuchus (Textfig. 14c) and eryopids (Sawin 1941, Boy 1990, Werneburg 2007, Werneburg et al. 2010). In Korkonterpeton kalnense gen. et sp. nov., the premaxillar ridge is also transverse and runs anteriorly along the premaxilla-maxilla suture. Only the postparietal ridge is very narrow and typically runs along the posterior skull table margin.

The lateral line sulci are not well developed in Korkonterpeton kalnense gen. et sp. nov.: only the narrow infraorbital sulcus is relatively marked but partly visible 

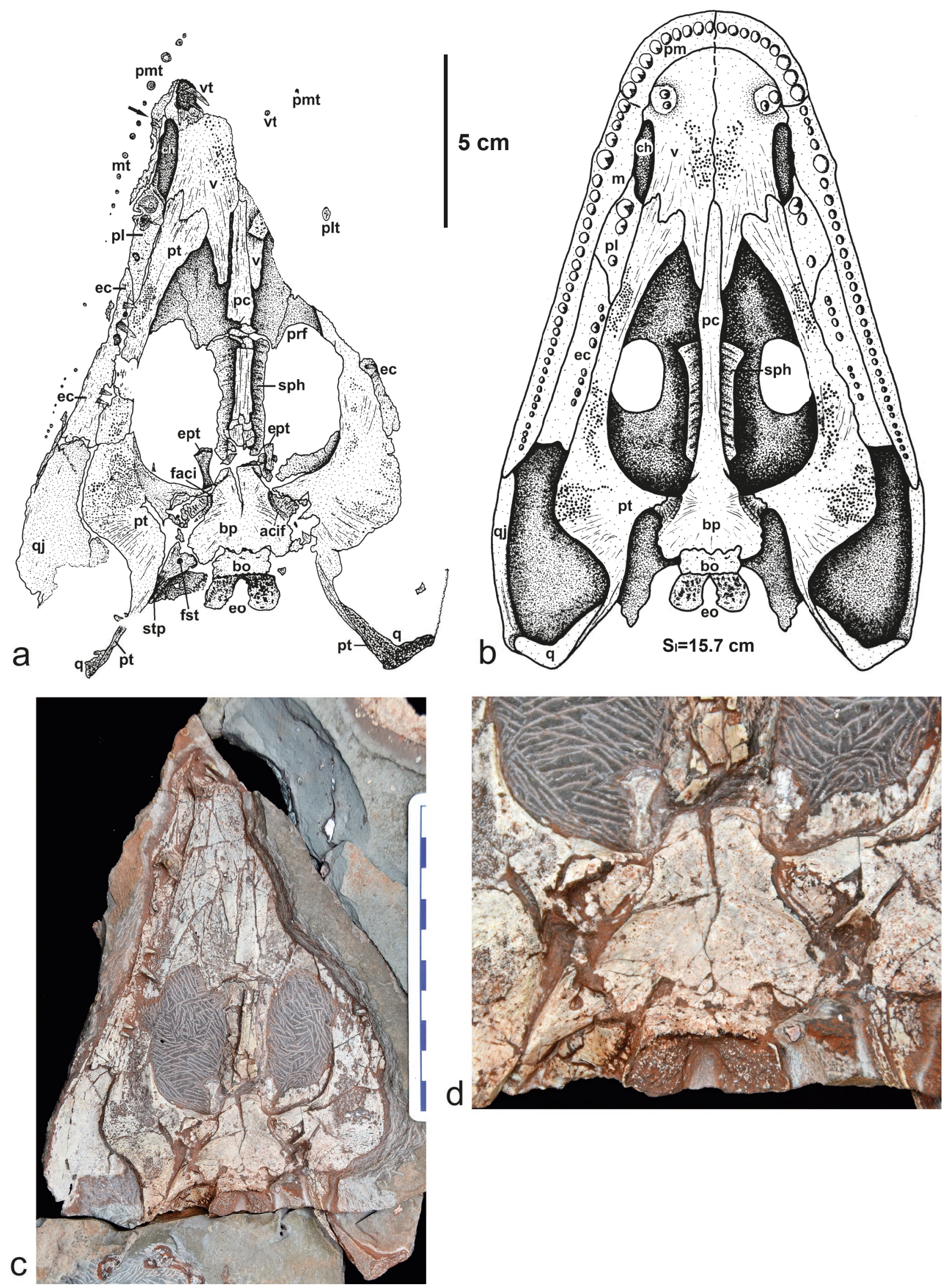

Text-fig. 6. The ventral palate with braincase of Korkonterpeton kalnense gen. et sp. nov., holotype MEBHK - P 82447. a, c, d: in situ-record, b: tentative reconstruction. Abbreviations: acif - furrow of arteria carotis interna, bo - basioccipital, bp - basal plate of parasphenoid, ch - choane, ec - ectopterygoid, eo - exoccipital, ept - epipterygoid, faci - foramen of arteria carotis interna, f.stp - stapedial foramen, $\mathbf{m}$ - maxilla, $\mathbf{m t}$ - maxillary teeth, pc - cultriform process of parasphenoid, pl - palatine, plt - palatine 
only on the postorbital and suborbital regions (ifc.pt unique deeply marked and ifc.sb respectively, Text-fig. $3 \mathrm{~b}$ ).

Palate (Text-figs 6, 15). The palate is well preserved and reveals interesting details concerning the dentition: the premaxilla bears about nine teeth, the three last ones being the largest - they are also larger than the anterior teeth of the maxilla. The fifth tooth of the maxilla, at mid-length of the choana, is a tusk that is supported by a small lateral expansion of the bone. Posteriorly to this tusk, are about 25 maxillary teeth decreasing progressively in size. Medially, at the level of the choana, the maxilla also widens, as in Intasuchus.

The vomer is a very large and developed bone, covering most of the palatal surface of the snout. The vomerian tusks are double and located in a circular small depression surrounded by a bony crest. Surprisingly, they are anterior to the choana, and even anterior to the premaxilla-maxilla suture, a unique character within stereospondylomorphs. The vomer and the pterygoid are covered by numerous small denticles arranged in clusters. The posteromedial process of the vomer is very elongated along the cultriform process of the parasphenoid: it reaches the level of the posterior tip of the palatine, as in Glanochthon but not in Intasuchus.

The choana is very narrow and slit-like, as in all stereospondylomorphs (Text-fig. 15), but it is narrower than that of Sclerocephalus and shorter than that of Archegosaurus.

The ectopterygoid, twice the length of the palatine, bears 8-10 relatively small teeth, except for the third and fourth which have the same diameter as the vomerian tusks (Textfig. $6 \mathrm{a}-\mathrm{c})$. The posterior width of the bone is similar to the anterior width, as in Archegosaurus (Witzmann 2006: fig. $3 b)$, but its posterior part is wider than in Glanochthon and Intasuchus (Text-fig. 15a, c).

The palatine is of similar length to the choana. It bears 3-5 teeth, the two anterior ones being the palatine tusks. These tusks are however smaller than those of Glanochthon or Intasuchus.

The pterygoid has a very short basipterygoid ramus in contrast to Intasuchus. Its quadrate ramus is ventrally very narrow and sutures posteriorly with the very elongate quadrate. The palatine ramus is curved medially and its anterior extremity is very wide $(2 / 3$ the width of the vomer) and bilobed: its anterolateral lobe is anterior to the posterior tip of the choana. This palatine ramus is similar in proportion to that of Intasuchus, but much wider than that of Glanochthon. The transversal process of the pterygoid is laterally swollen.

The parasphenoid has a relatively short basal plate in comparison with other stereospondylomorphs. The cultriform process is narrow but slightly widens at half its length, posteriorly to the vomer and anteriorly to the sphenethmoid. The anterior third of the cultriform process is embedded in the vomer (contra the anterior half in Sclerocephalus and Glanochthon; Schoch and Witzmann $2009 a, b)$. The anterior tip of the cultriform process reaches the same level as the posterior extremity of the choana (in
Sclerocephalus and Glanochthon, it reaches half the length of the choana). In Korkonterpeton kalnense gen. et sp. nov., the basipterygoid process of the parasphenoid is located anterolaterally on the basal plate, as in Intasuchus but not in Glanochthon nor in Sclerocephalus. At the base of this basipterygoid process, a fine groove for the carotid artery is visible: it ends anteriorly by the carotid foramen. The basal plate of the parasphenoid is ventrally smooth as in Glanochthon, but not in Intasuchus.

Braincase (Text-fig. 6). The sphenethmoid and epipterygoids are well ossified (the epipterygoids are missing at this ontogenetical stage in Glanochthon and Archegosaurus; Witzmann 2006, Schoch and Witzmann 2009b). The sphenethmoid lies dorsally above the cultriform process: it has an elongate rhombic shape with an anteriorly wider region, as in Sclerocephalus haeuseri GoLDFuss, 1847 (where this bone is still shorter; Schoch and Witzmann 2009a: fig. 6B) but not in the eryopids (where it is arrowhead-like; Sawin 1941, Werneburg 2007, Werneburg and Berman 2012).

The epipterygoid (Text-fig. 6a, c-d) has a broad base, a poorly ossified end and a slender shaft. The unpaired basibranchial is similar in shape but much larger than the epipterygoid (the basibranchial is recorded in Glanochthon, Sclerocephalus and Archegosaurus; see Witzmann 2006, Schoch and Witzmann 2009a, b). The basioccipital is relatively short and sutures the basal plate of the parasphenoid at the two-third region of its posterior margin. The exoccipital, which forms the occipital condyle, is very elongate posteriorly, a unique character within stereospondylomorphs.

The quadrate is ventrally a large hook-shaped and wellossified bone. Its medial suture with the quadrate ramus of the pterygoid is very elongate and oblique. As described above, this bone dorsally presents a quadrate boss.

Visceral skeleton (Text-fig. 6a, c, d). The stapes is preserved in the right otic notch: it has a wide footplate (width 8 or $13 \mathrm{~mm}$ ) and an apparently relatively short and slender shaft (recorded length $19 \mathrm{~mm}$ ). The quadrate process is not visible here (contra Sclerocephalus and Archegosaurus; Witzmann 2006, Schoch and Witzmann 2009a).

Mandible (Text-fig. 7). The mandible is well preserved, with its left hemimandible complete: it is relatively long (length $=205 \mathrm{~mm}$ ) and shallow (height $=37 \mathrm{~mm}$ ) compared with others stereospondylomorphs. The surangular is clearly visible but its suture with the angular remains difficult to detect precisely. The dorsolabial portion of this surangular is straight and very slightly ornamented. The surangular process is very flat. The articular is a relatively small bone (length $=18 \mathrm{~mm}$ ) within the complete hemimandible. Dorsolingually, it forms an elongated and deeply concaved joint socket (Text-fig. 7c). Just ventrally to this socket, the articular-prearticular suture runs anteroposteriorly straight in lingual view. The foramen for the chorda tympani lies ventrally to this suture, in the posterior portion of the prearticular: this foramen is very shallow but relatively elongate (length $=10 \mathrm{~mm}$ ). Labially, the angular and the postsplenial are well ornamented. The mandibular sulcus is

tooth, pm - premaxilla, pmt - premaxillary teeth, prf - prefrontal, ps - parasphenoid, pt - pterygoid, q - quadrate, qj - quadratojugal, sph - sphenethmoid, stp - stapes, v - vomer, vt - vomerian tooth. Sl - midline skull length. 

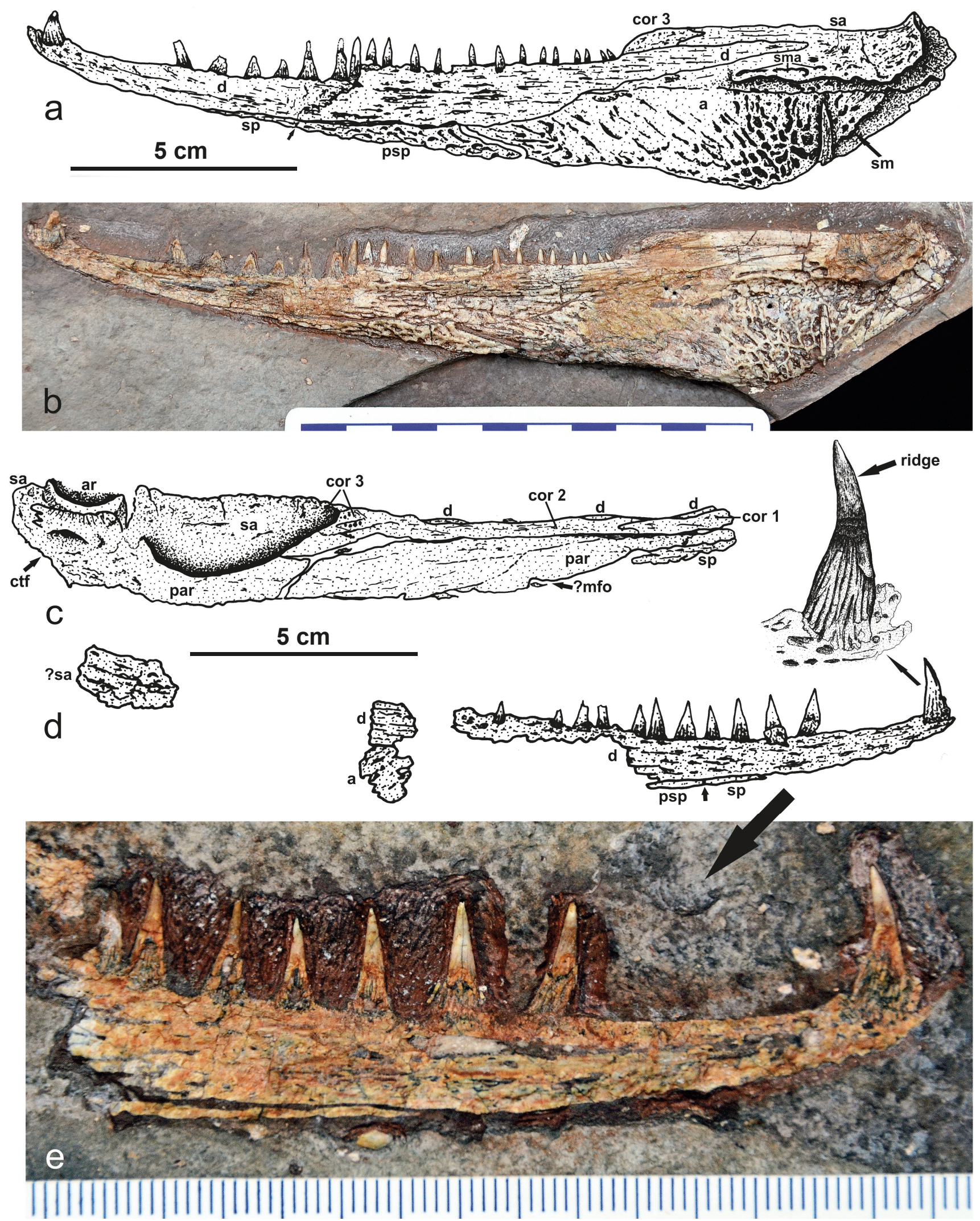

Text-fig. 7. The mandibles of Korkonterpeton kalnense gen. et sp. nov., holotype MEBHK - P 82447. a, b: in labial view, c-e: in lingual view. Abbreviations: a - angular, ar - articular, cor - coronoid, ctf - foramen for chorda tympani, d - dentary, mfo meckelian foramen, par - prearticular, psp - postsplenial, sa - surangular, sm - mandibular sulcus, sma - accessory mandibular sulcus, sp - splenial.

clearly visible in the posterior region of the hemimandible, in labial view it consists of a smooth straight groove at the level of the angular-surangular suture. Three other larger grooves are also visible on the labial surface of the surangular: they represent the accessory mandibular sulcus, as in Archegosaurus decheni (Witzmann 2006: figs 21, 22). The splenial is relatively short (length $=22 \mathrm{~mm}$ ) in labial view. The dentary is the longest bone of the hemimandible 

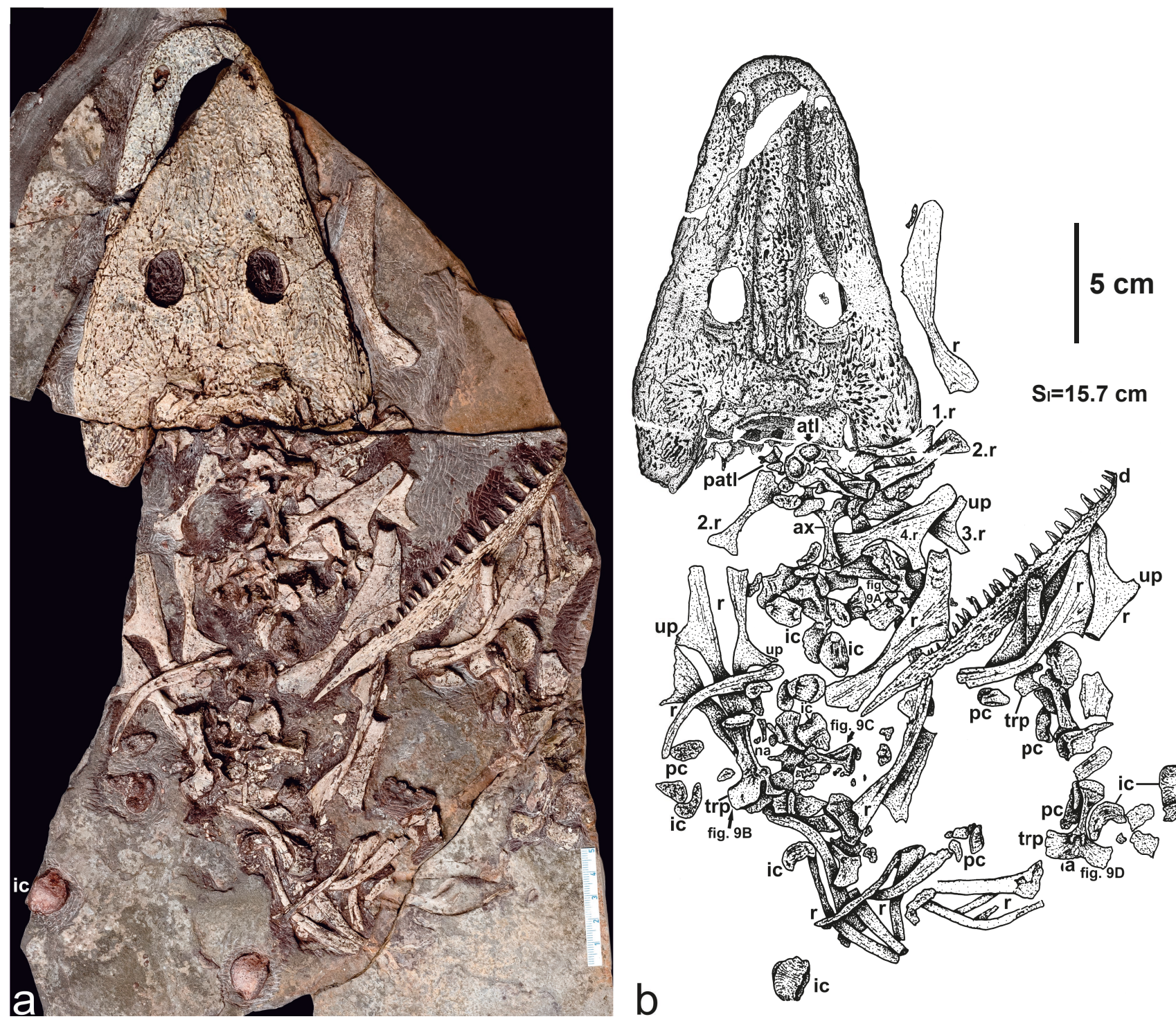

$S_{1}=15.7 \mathrm{~cm}$

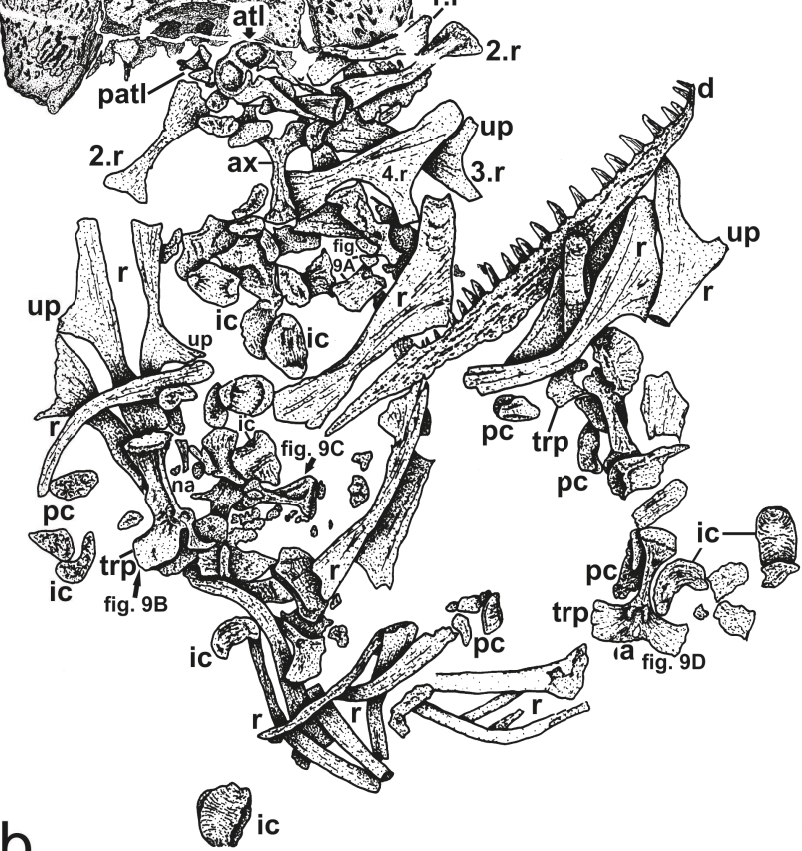

Text-fig. 8. Cranial and postcranial skeleton of Korkonterpeton kalnense gen. et sp. nov., holotype MEBHK - P 82447. a, b: in siturecord. Abbreviations: atl - atlas, ax - axis, d - dentary, ic - intercentrum, na - neural arch, patl - preatlas, pc - pleurocentrum, $\mathbf{r}$ - rib, trp - transversal process of neural arch, up - uncinated process of rib.

(length $=173 \mathrm{~mm}$ ). It is slightly ornamented labially. The left dentary bears 21 preserved teeth, whose general size decreases posteriorly along the lower jaw. However, the anterior third and fourth teeth are smaller than the posterior ones. The largest tooth of the most anterior dental exhibits an anterior blade. In conclusion, the mandibular anatomy of Korkonterpeton kalnense gen. et sp. is very similar to that of the others stereospondylomorphs (e.g., Boy 1993, Schoch and Witzmann 2009a, Witzmann 2006).

Postcranium (Text-figs 8-11). The postcranial skeleton is only represented by its axial skeleton. The anterior vertebrae and ribs are well preserved. The atlas-axiscomplex is especially completely recorded (Text-figs 8-9, 10a, b). The atlas consists of a transversely narrow intercentrum fused to the neural arch. The notochord opening dorsally divides the centrum into two lateral lobes with the exoccipital facets in anterior view, as in Platyoposaurus stuckenbergi (Gubin 1991: fig. 27). The thin low neural spine of the atlas consists of two processes that do not meet dorsally. A rudimentary transverse process is exposed on the concave lateral flank of the neural arch, as in Sclerocephalus (Schoch and
Witzmann 2009a). The postzygapophysis is substantial for articulation with the axis. The prezygapophysis of the atlas is very distinctively exposed with an oval shape in anterior view. The proatlas is also preserved: its small neural arch has a globular bellied shape (Text-figs 8,9). It was clearly in articulation with the atlas, as in Eryops (Moulton 1974), Sclerocephalus (Boy 1988, Schoch and Witzmann 2009a) and Archegosaurus (Witzmann and Schoch 2006).

The axis bears a very robust neural spine, which is much more massive in anterior or posterior view than that of the atlas. It has an enlarged dorsal top and strong transverse processes. The first anterior rib articulates with the axis: this rib is very short and shows no clear uncinate process. The second rib articulates with vertebrae III and is more elongated than the first rib. It has enlarged ends and a very small hook-like uncinate process (Text-fig. 9). The third, fourth and following anterior ribs are larger and have particularly elongated uncinate processes. Usually 13 anterior thoracic ribs with large uncinate processes are known in Sclerocephalus (Boy 1988), but this number may be lower in Korkonterpeton kalnense gen. et sp. nov. The 


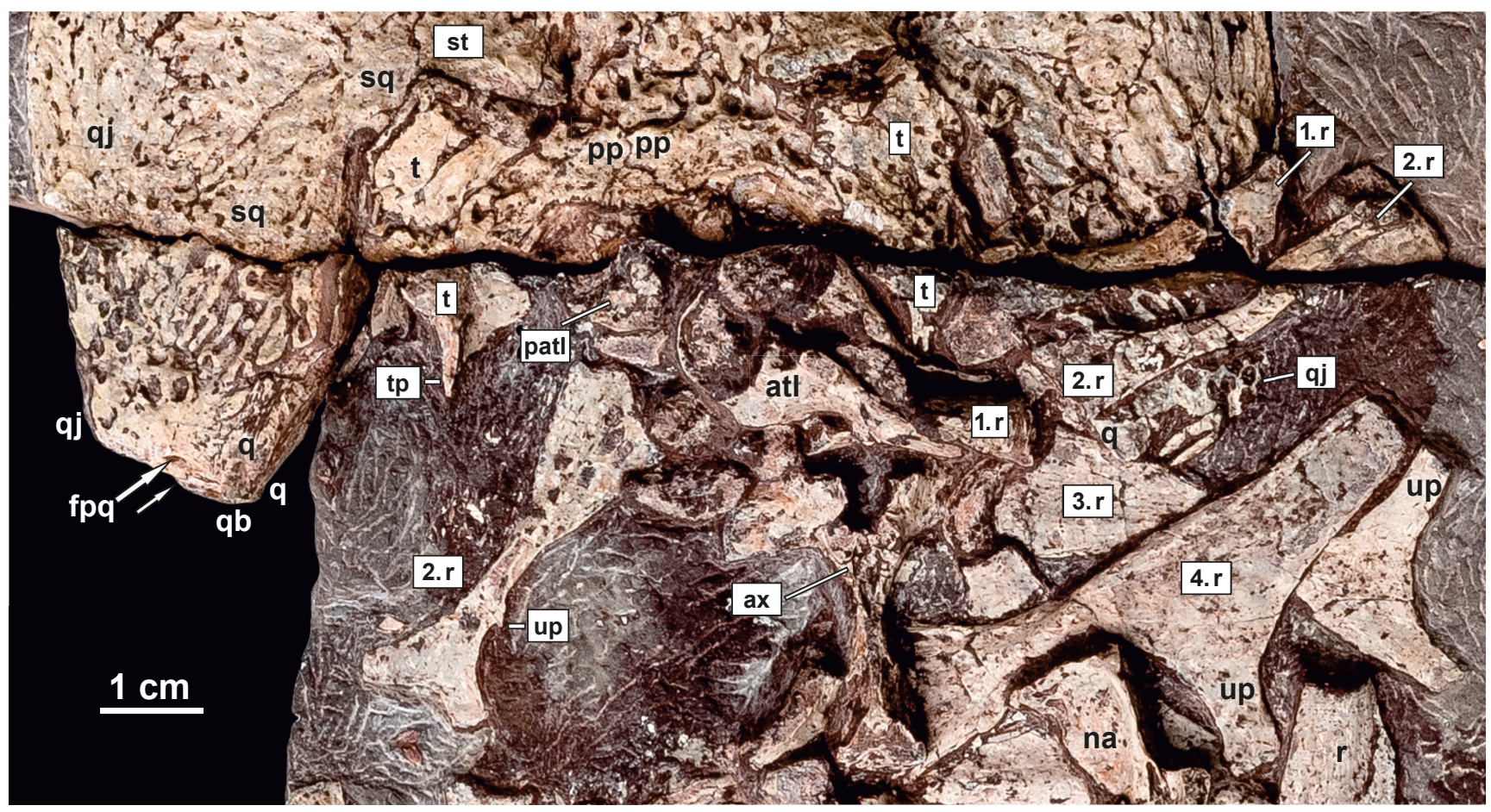

Text-fig. 9. Posterior skull with anterior postcranial skeleton of Korkonterpeton kalnense gen. et sp. nov. in dorsal view. Abbreviations: atl - atlas, ax - axis, f.pq - quadratojugal foramen, na - neural arch, patl - preatlas, pp - postparietal, q - quadrate, qb - quadrate boss, qj - quadratojugal, $r$ - rib, sq - squamosal, st - supratemporal, $t$ - tabular, tp - tabular process, up - uncinated process of rib.

posterior ribs, shorter and narrower than the anterior ones, have no processes. The neural arch of vertebra III (Textfig. 11a) shows oval and sculptured elements on the lateral side of its neural spine. The top of this spine is greatly enlarged as a transversal process. This transversal process laterally presents the diapophysis and a pleurocentral facet in posterior view. The vertebrae V-VIII also have expanded transversal processes and very narrow neural spines. The lateral flanks of these spines are smooth. The dorsal top of the spines is extremely expanded and forms a large oval, rough surface with a rugose margin (Text-fig. 11b). The smaller and more posterior vertebrae are illustrated in lateral view in Text-fig. 10c-e. The centra are well ossified. The intercentra are large and form robust crescent shaped elements. Their dorsal surface is rugose, whereas their ventral and lateral surfaces are smooth and slightly concave. The parapophyses are fully ossified. The paired, narrow-oval pleurocentra have smooth and concave lateral flanks. The pattern of these centra is clearly rhachitomous and very similar to those of stereospondylomorphs and eryopids (Moulton 1974, Boy 1988, 1990, Witzmann and Schoch 2006, Werneburg 2007, Schoch and Witzmann 2009a,).

The ventral scalation is poorly preserved. Only a few spindle-like ventral scales are recorded (Text-fig. 9, below the right quadratojugal).

Comparison with Memonomenos dyscriton $\mathrm{S}$ TEEN, 1938. Another stereospondylomorph anterior skeleton is known from the Czech Krkonoše Piedmont Basin: Memonomenos dyscriton STEEN, 1938, from the early Asselian Rudník Horizon (Vrchlabí Formation) of Koštálov, 36 km west of Trutnov. Milner (1978), Schoch and Milner (2000) and Witzmann (2006) placed this species in the genus Archegosaurus, later Schoch and Witzmann (2009b) established the validity of the genus Memonomenos as well as its close relationships with Intasuchus. However, this species most likely belongs to the Archegosauridae, not to Intasuchidae according to our observations (see Tab. 1): its posterior and middle skull width, its posterior skull table, its jugal/cheek and nostrils are indeed narrow, as is the case in the Archegosauridae. However, Memonomenos dyscriton differs from Archegosaurus decheni in having a wider anterior skull, a smaller ratio between the pre- and postorbital length $(\mathrm{PO} / \mathrm{Hl}=1.91)$, a shorter lacrimal, more elongated nostrils, and a slightly wider jugal. Two characters of $M$. dyscriton may be unique: the similar intranarial and intraorbital distances $\left(\mathrm{INw}_{\mathrm{w}} / \mathrm{S} 1=\mathrm{IO}_{\mathrm{w}} / \mathrm{S} 1=0.13\right)$, and the relatively narrow jugal $\left(\mathrm{J}_{\mathrm{W}} / \mathrm{Sl}=0.06\right)$.

\section{Family Intasuchidae KonZHukova, 1956}

Type genus. Intasuchus Konzhukova, 1956.

Emended diagnosis. Unique character combination in Stereospondylomorpha:

(1) Lacrimal entering the septomaxilla (shared with the Eryopidae; the contact of both bones in the late adult Cheliderpeton is uncertain; compare Text-fig. 14d, e).

(2) Wide jugal $\left(\mathrm{J}_{\mathrm{W}} / \mathrm{S} 1=0.16\right.$; similar only in Sclerocephalus).

(3) Interpterygoid vacuity widened posterolaterally.

(4) Subtemporal window elongated anteriorly up to a point in the anterior half orbit.

(5) Pterygoid with very elongated basipterygoid ramus which is as long as the orbit is wide, and with relatively long contact with the parasphenoid.

(6) Vomer with a parachoanal tooth row but without a tusk present. 

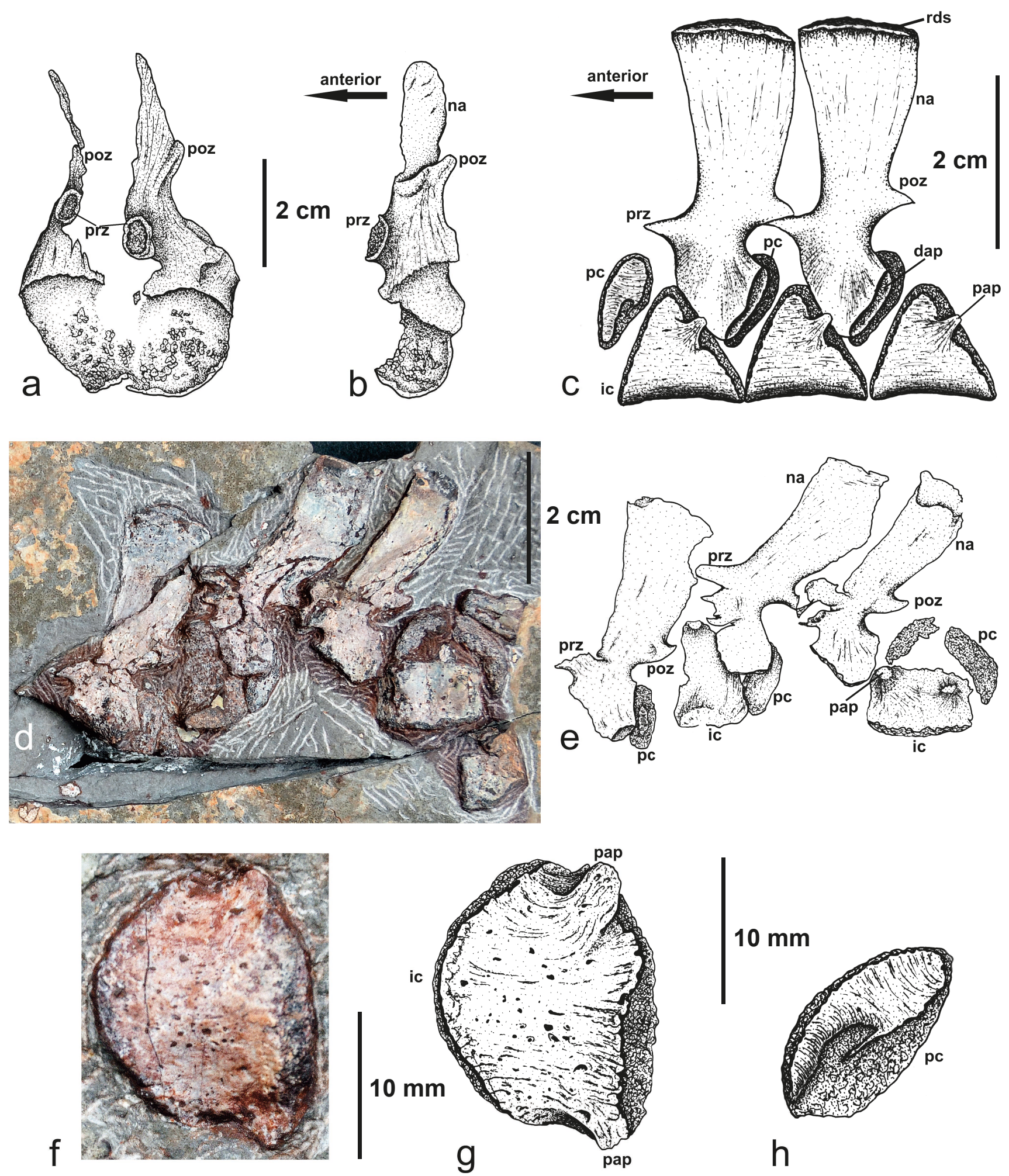

Text-fig. 10. Vertebrae of Korkonterpeton kalnense gen. et sp. nov. a, b: atlas in anterior and lateral view, c: tentative reconstruction of posterior vertebrae in lateral view, $d$, $e$ : in situ record of posterior vertebrae, compare (c), $f$, g: intercentrum in ventral view, h: pleurocentrum in lateral view. Abbreviations: dap - diapophysis, fpc - facet for pleurocentrum, ic - intercentrum, na - neural arch, pap - parapophysis, pc - pleurocentrum, poz - postzygapophysis, prz - praezygapophysis, rds - roughened dorsal surface of neural arch.

(7) Ectopterygoid of similar length as the palatine (similar in Sclerocephalidae) and posteriorly reaching a point in the anterior half of the orbit.

Content. Intasuchus Konzhukova, 1956, from the lower Permian of the Russian Inta-region.
$\mathrm{R}$ e $\mathrm{m}$ a r k . Although we only know the genus Intasuchus within the Intasuchidae up to now, the diagnosis of the family is newly proposed here based on its most important differences compared with related families and genera. This diagnosis will be adapted following by the possible erection of other genus or genera. 
Genus Intasuchus KonZhuKova, 1956

Ty p e s pe c i es. Intasuchus silvicola Konzhukova, 1956

Emended diagnosis. Unique characters among stereospondylomorphs:

(1) Intranarial distance smaller than the intraorbital one.

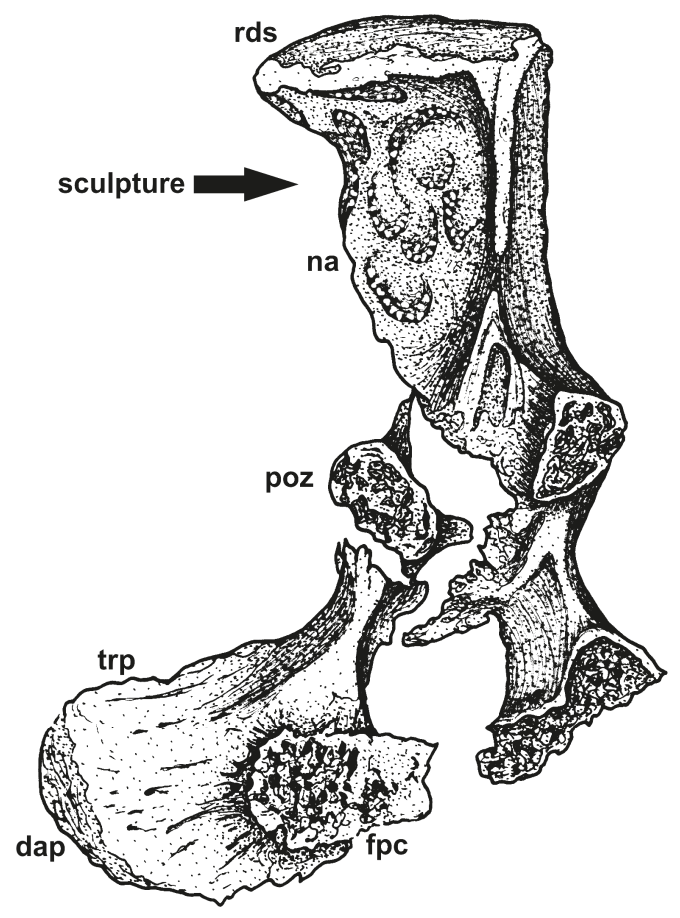

a

C

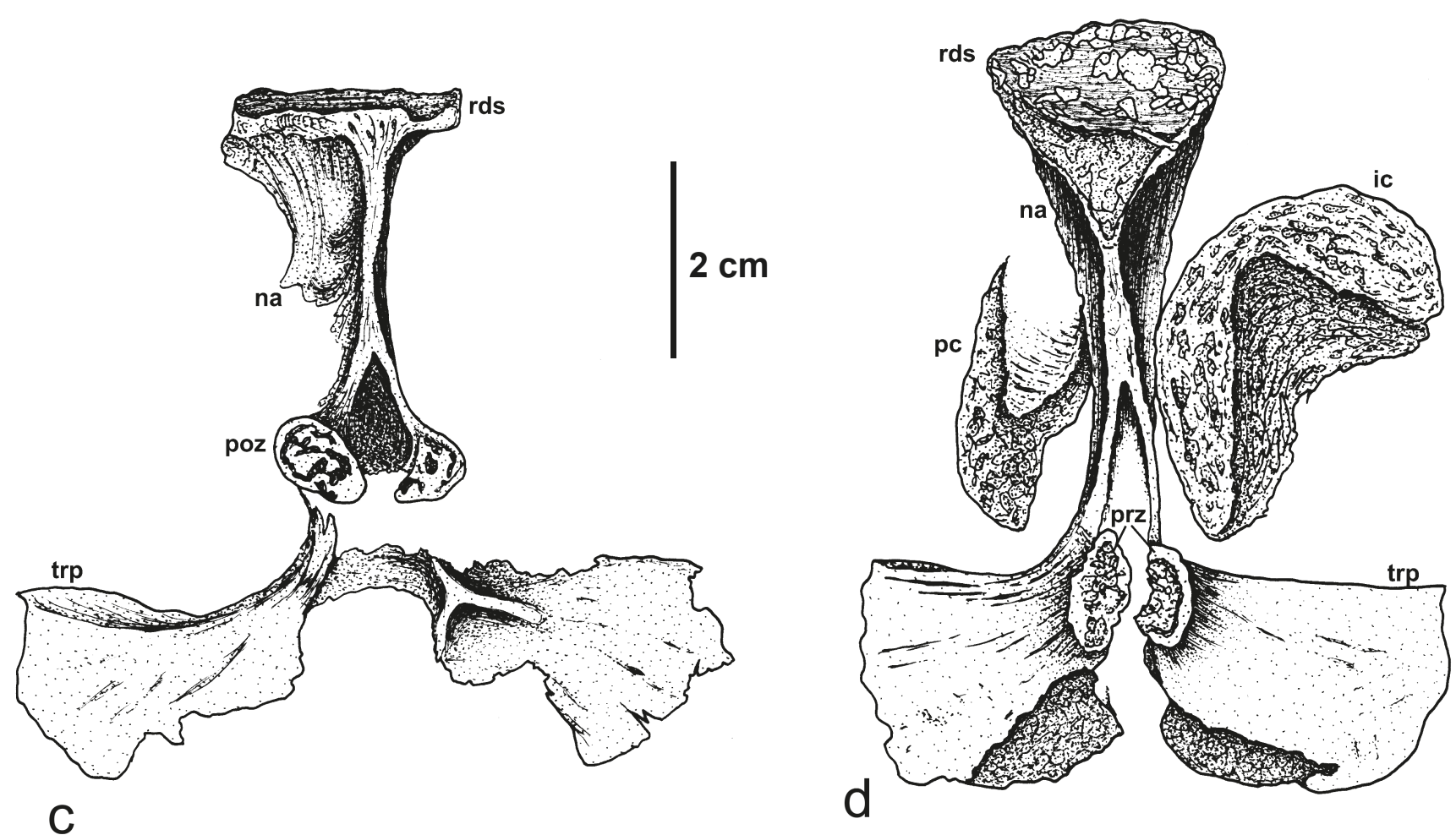

(2) Posterior part of the postfrontal extremely elongated and reaching a level clearly posterior to the pineal foramen.

Characters in contrast to distinct stereospondylomorph genera, but shared with others:

(3) Preorbital length 2.35 times that of the postorbital region (similar in Glanochthon; Schoch and Witzmann 2009b).

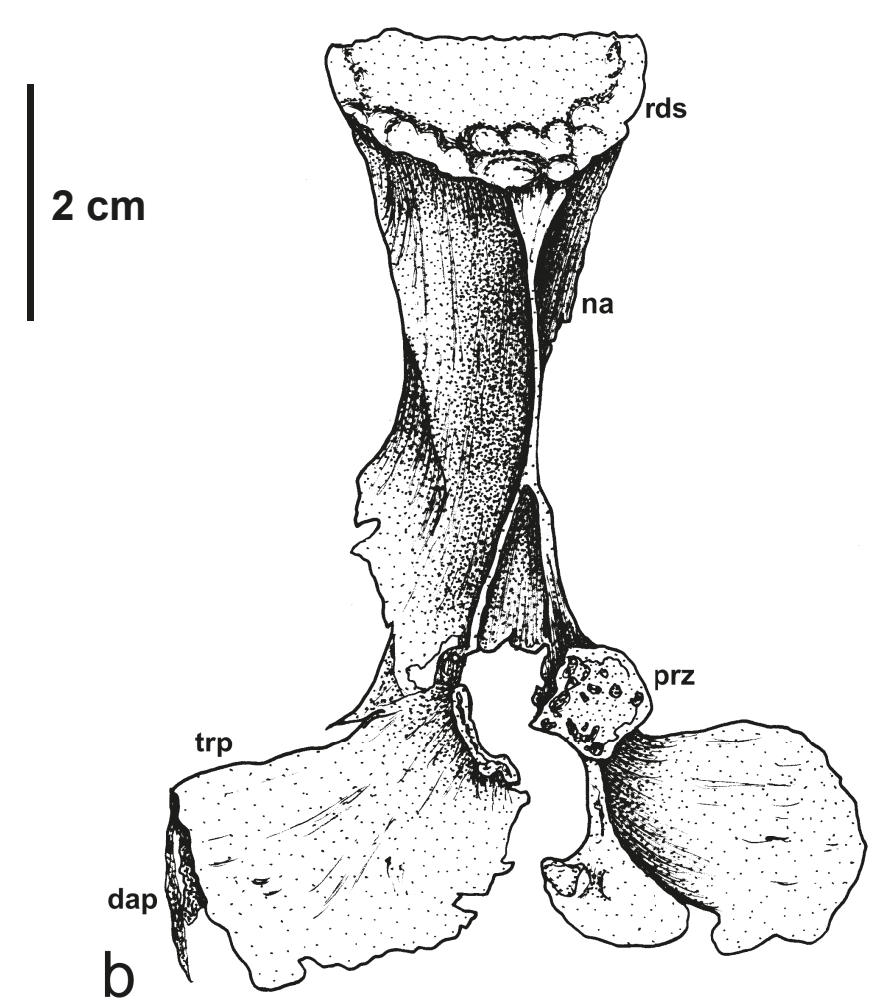

Text-fig. 11. Neural arches of Korkonterpeton kalnense gen. et sp. nov. a: vertebra III in posterolateral view, b: vertebra VI or VII in anterolateral view, c: vertebra $\mathrm{V}$ or VI in posterior view, $d$ : vertebra VIII in anterior view with intercentrum and pleurocentrum. Abbreviations: dap - diapophysis, fpc - facet for pleurocentrum, ic - intercentrum, na - neural arch, pc - pleurocentrum, poz postzygapophysis, prz - praezygapophysis, rds - roughened dorsal surface of neural arch, trp - transversal process of neural arch. 

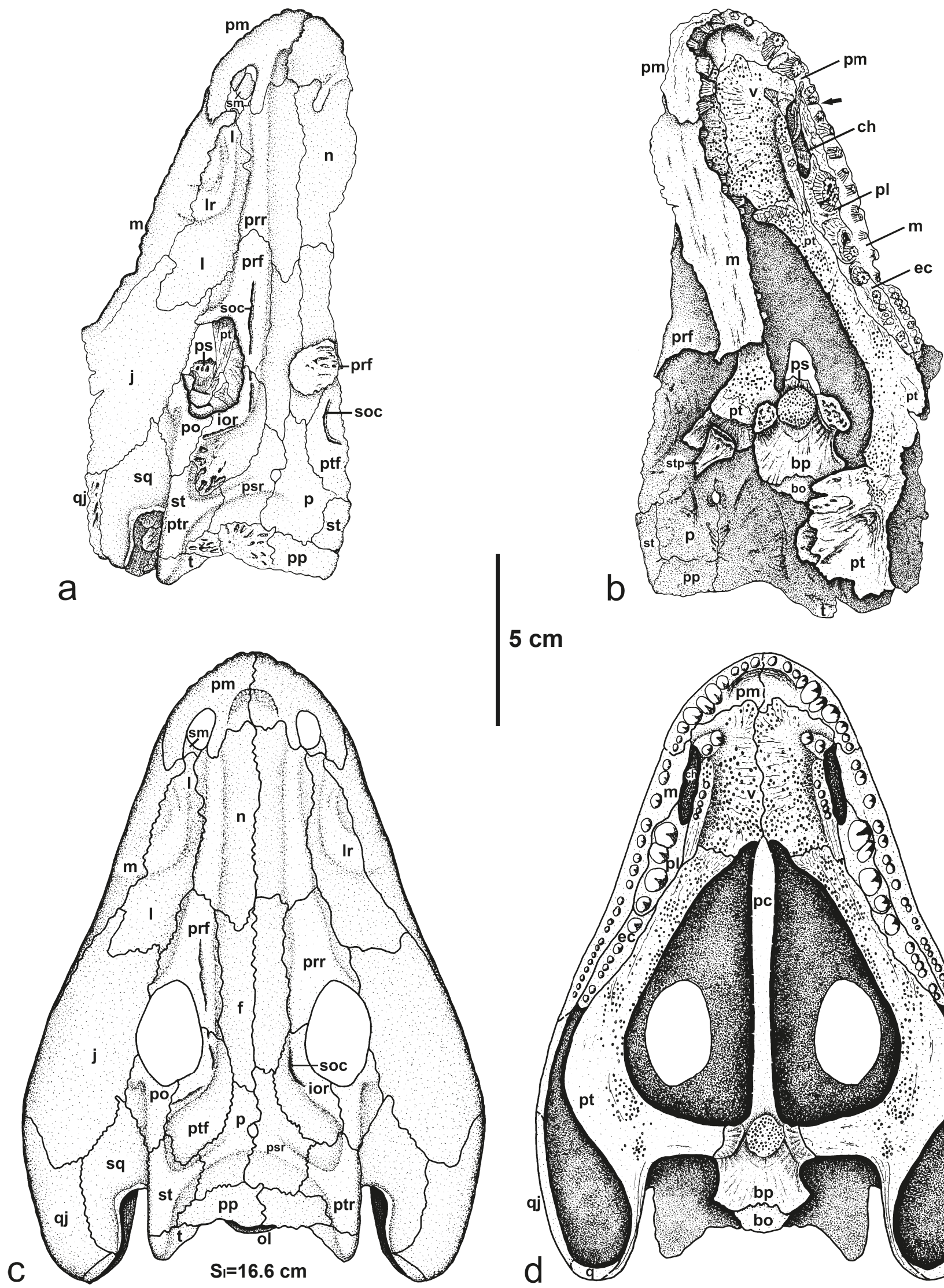

$5 \mathrm{~cm}$

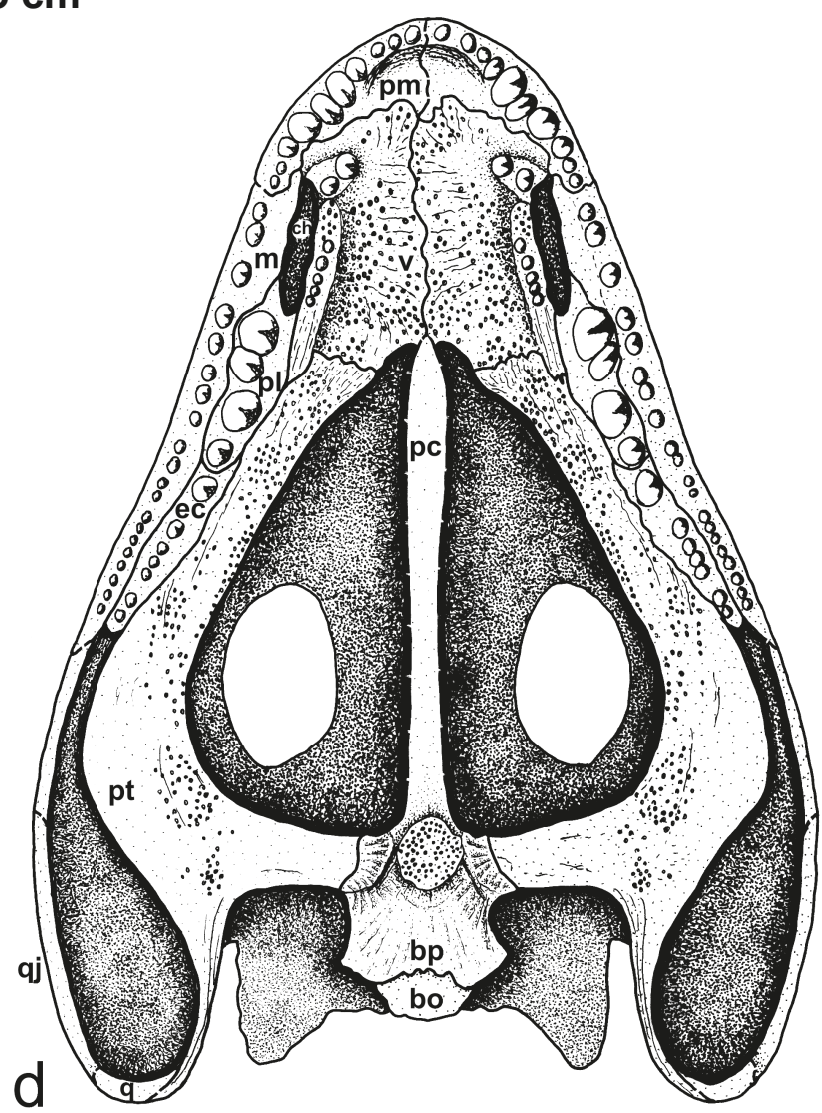

Text-fig. 12. The skull of Intasuchus silvicola Kоnzникоva, 1956. a, c: dorsal skull roof, in situ-record and tentative reconstruction, b, d: ventral palatal skull, in situ-record and tentative reconstruction. Abbreviations: bo - basioccipital, bp - basal plate of parasphenoid, ch - choane, ec - ectopterygoid, $\mathbf{f}$ - frontal, ior - intraorbital ridges, $\mathbf{j}$ - jugal, l - lacrimal, lr - lacrimal ridge, m - maxilla, $\mathbf{n}$ - nasal, ol - occipital lamella, $\mathbf{p}$ - parietal, pc - cultriform process of parasphenoid, pl - palatine, pm - premaxilla, po - postorbital, pp - postparietal, prf - prefrontal, prr - prefrontal ridge, ps - parasphenoid, psr - parietal-supratemporal ridge, pt - pterygoid, ptf - postfrontal, ptr - postorbital-tabular ridge, q - quadrate, qj - quadratojugal, sm - septomaxilla, soc supraoccipital sulcus, sq - squamosal, st - supratemporal, stp - stapes, $\mathrm{t}$ - tabular, v - vomer. Sl - midline skull length. 
(4) Premaxillary region narrow $(\mathrm{aSw} / \mathrm{S} 1=0.31)$ and pointed, with a relatively elongated median portion (shared with Cheliderpeton; Werneburg and Steyer 2002). (5) Maxilla slightly concave laterally (comparable with Glanochthon; Schoch and Witzmann 2009b).

(6) Maximal width of the skull at the level of the pineal foramen and the anterior region of the quadratojugal $(\mathrm{pS} \mathrm{w}=0.80$, similar in Korkonterpeton kalnense gen. et sp. nov.).

(7) 'Otic notch' (squamosal embayment) very deep and wide. The short suture between the squamosal and the supratemporal starts posteriorly at half the length of the supratemporal (similar in late adult Cheliderpeton).

(8) Narrow anterior part of the nasal (shared with Archegosaurus and the late adult Cheliderpeton).

(9) Ventral premaxilla-maxilla-suture at the posterior end of the choana (shared with Glanochthon and Sclerocephalus; Schoch and Witzmann 2009a, b).

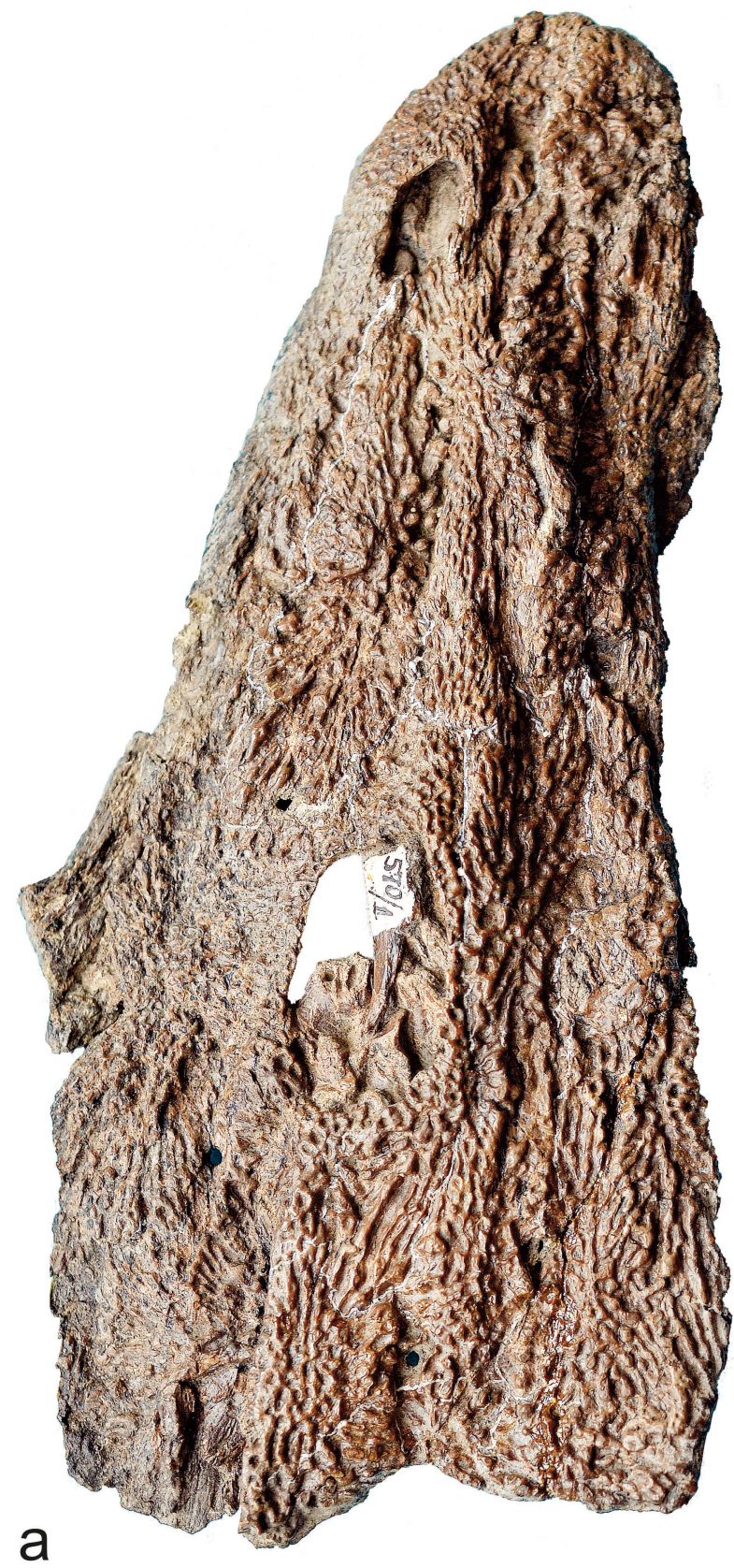

(10) Parachoanal vomerine tooth row on a higher elevation parallel to the medial choana (shared with Archegosaurus). (11) Vomerine fangs very close to the anteromedian margin of the choana (shared with Glanochthon and Sclerocephalus).

(12) Ectopterygoid with one or two large fangs (shared with Sclerocephalus and similar in size to Glanochthon). (13) Anterior part of the pterygoid reaching a level posterior to the choana (shared with Glanochthon, Sclerocephalus and Archegosaurus).

(14) Narrow basal plate of the parasphenoid (shared with Archegosaurus).

(15) Basal plate of the parasphenoid with a central, ovoid and elevated patch covered by denticles (shared with Archegosaurus).

R e m a rk. Although we only know the unique species Intasuchus silvicola KonzhuKovA, 1956 within Intasuchus

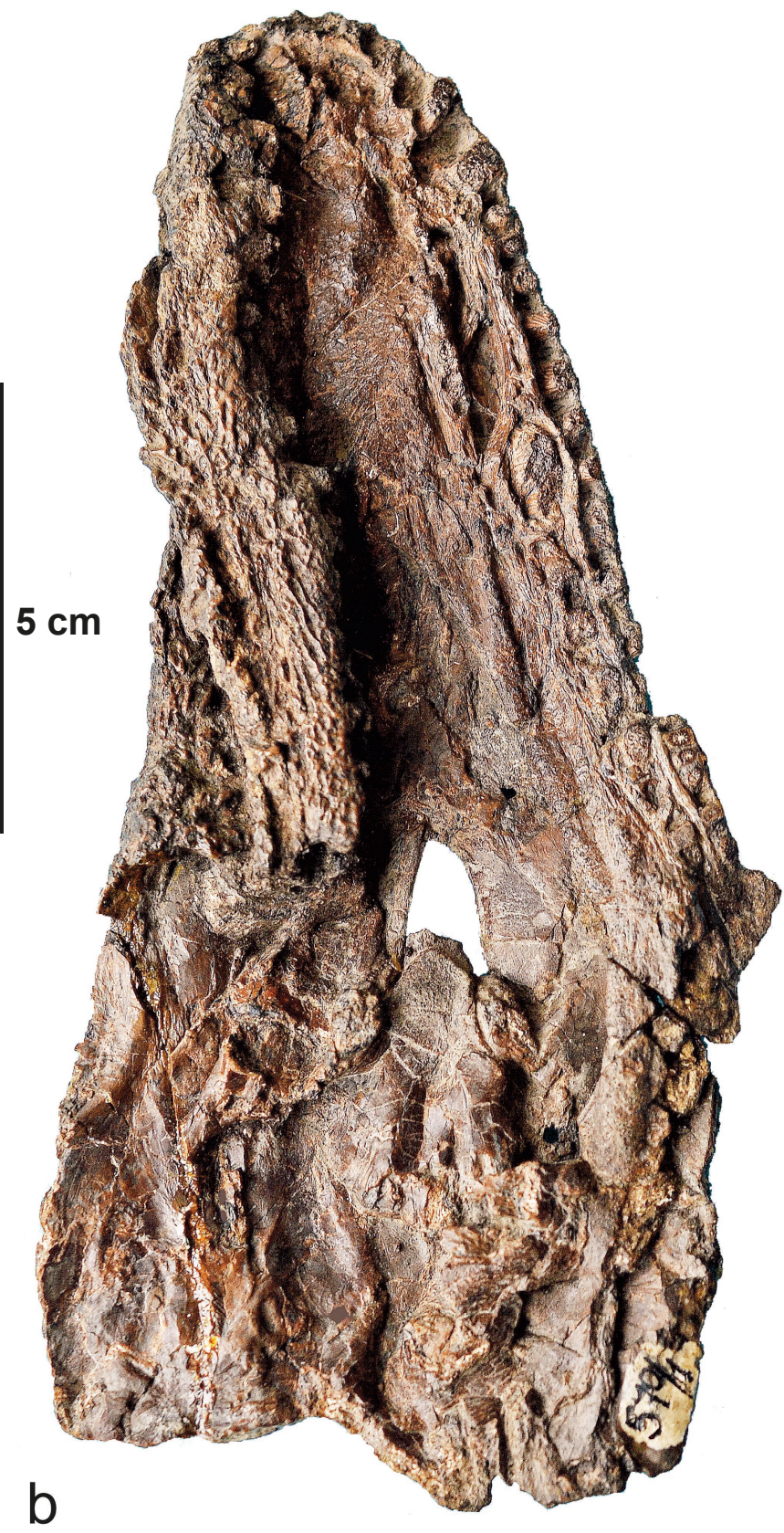

Text-fig. 13. The skull of Intasuchus silvicola Konzhuкоva, 1956, holotype PIN 570/1. a: dorsal skull roof, b: ventral palatal skull. 
up to now, the new diagnosis of the genus proposed here is based on the most important differences when compared to related genera. This diagnosis will be adapted by the possible discovery of other species.

\section{Intasuchus silvicola KonZHUKOVA, 1956 Text-figs 12,13}

Holotype. PIN 570/1, housed in Paleontological Institute, Russian Academy of Sciences, Moscow, Russia.

Type horizon. Intinskian Formation.

A ge. Ufimian, late Kungurian (273-274 Ma, after Schneider et al. 2020), Cisuralian, lower Permian.

Ty p e 1 o c a 1 i t y. Coal mine near 'Greater Inta River', Komi Republic, northeastern European Russia.

Emended diagnosis. Unique characters among stereospondylomorphs:

(1) Lacrimal very elongated and longer than the nasal

(2) Parietal and supratemporal relatively short and wide.

Characters in contrast to specific stereospondylomorph species, but shared with others:

(3) Elongated alary process of the premaxilla reaching posteriorly to a level in the middle region of the septomaxilla (similar in Korkonterpeton kalnense gen. et sp. nov.).

(4) Anteriorly wide and blunt prefrontal, reaching anteriorly a level in the anterior region of the frontal (shared with late adult $C$. vranyi).

(5) Posteriorly narrow squamosal, but not going beyond the posterior region of the tabular (similar in Korkonterpeton kalnense sp. nov. and C. vranyi).

(6) Very short tabular (shared with Glanochthon).

(7) Tabular - supratemporal suture lying at the level of the posteromedian margin of the skull table (as in G. angusta).

(8) Elongated postparietal (shared with Glanochthon and Cheliderpeton).

(9) Slightly concave posterior skull margin (as in $C$. vranyi).

(10) Palatine with two pairs of fangs - the largest teeth of dentition (shared with Glanochthon).

(11) Anterior palatine ramus of the pterygoid medially curved (shared with Archegosaurus and Korkonterpeton kalnense gen. et sp. nov.).

(12) Anterior tip of the parasphenoid cultriform process reaching the level of the anterior region of the pterygoid (shared with Archegosaurus and Korkonterpeton kalnense sp. nov.).

(13) Basipterygoid process of the basal plate large, anterolaterally directed and long sutured with the basipterygoid process of the pterygoid (similar as in Korkonterpeton kalnense gen. et sp. nov.).

Comparative description. General morphology. The holotype represeneted by the skull of Intasuchus silvicola KonZHUKOvA, 1956 is well preserved in dorsal and palatal views (Text-fig. 13), only the posterolateral cheek and the quadrate region are missing. The skull has a midline length of $16.6 \mathrm{~cm}$. The dermal ornamentation of the skull roof is exquisitely preserved: it consists of a dense pattern of central polygons and radial ridges on the margin of the bones. Together with the strong degree of ossification, this well-developed ornamentation pattern suggests an adult stage for this specimen (Steyer 2000b). The natural relief of the skull roof is also well preserved.

The new cranial reconstruction of Intasuchus proposed here (Text-fig. 12c, d) is very different from those of Konzhukova (1956) and Gubin (1984) which are incorrect because both authors used the specimen No. PIN 570/2 (Syndyodosuchus) for the posterior region and did not take into account the enormous width of the jugal.

Skull roof (Text-figs 12a, c, 13a, 14, Tab. 1). The skull has an extremely elongated preorbital region measuring 2.35 times the length of the postorbital region (Tab. 1: $\mathrm{PO} 1 / \mathrm{H} 1=2.35 ; \mathrm{PO} 1 / \mathrm{S} 1=0.57$ ). This postorbital region is indeed short $(\mathrm{Hl} / \mathrm{Sl}=0.24)$. The premaxillary snout region is narrow and pointed $(\mathrm{aSw} / \mathrm{S} 1=0.31)$. The premaxilla is moderately elongated, 1.4 times longer than the narial length. These two last characters are also seen in Cheliderpeton vranyi (Werneburg and Steyer 2002), but not in Korkonterpeton kalnense gen. et sp. nov., Glanochthon (Schoch and Witzmann 2009b) and Sclerocephalus (Boy 1988, Schoch and Witzmann 2009a). The distance between the nostrils is very short $\left(\mathrm{IN}_{\mathrm{W}} / \mathrm{S} 1=0.14\right)$ and smaller than the intraorbital distance $(\mathrm{IO} / \mathrm{S} 1=0.18$; in contrast to most other stereospondylomorphs, and only shared with Archegosaurus). The alary process of the premaxilla is elongated and posteriorly reaches a level in the middle region of the septomaxilla. The dorsal septomaxilla is relatively small but may be continued ventrally. Its posterior extremity is posterolaterally directed, in contrast to Glanochthon. The maxilla is slightly concave laterally, as is the case in Glanochthon (Schoch and Witzmann 2009b). It is dorsally relatively short and not in contact with the quadratojugal in dorsal view. The maxilla has no contact with the nasal, because the lacrimal enters the septomaxilla. The lacrimal is a very elongated and relatively wide. These two last characters are rarely seen in stereospondylomorphs except in the late adult $C$. vranyi. The nasal is narrow (in contrast to Korkonterpeton kalnense gen. et sp. nov.). The intraorbital region $\left(\mathrm{IOw}_{\mathrm{w}} / \mathrm{S} 1=0.18\right)$ and the frontals are also narrow. The orbit is large in size $(\mathrm{O} 1 / \mathrm{S} 1=0.19)$ and elongate in shape; it is the most elongated orbit within stereospondylomorphs (similar only in Archegosaurus). The postorbital region is short $(\mathrm{H} 1 / \mathrm{S} 1=0.24)$, in contrast to C. vranyi. The prefrontal is anteriorly wide and blunt, and it reaches the level of the anterior part of the frontal (shared with the late adult C. vranyi). The posterior process of the prefrontal and the anterior process of the postfrontal are wide, much wider than in the previous reconstructions by Konzhukova (1956) and Gubin (1984). The postfrontal is in clear contact with the prefrontal. The posterior part of the postfrontal is extremely elongated and reaches a level significantly posterior to the pineal foramen. This posterior process of the postfrontal forms an embayment in the anteromedial part of the supratemporal. These two last characters are unique in stereospondylomorphs. The postorbital is wide $(\mathrm{Pow} / \mathrm{Pol}=0.91)$ and relatively short. The jugal is anteriorly and especially posteriorly very wide $\left(\mathrm{J}_{\mathrm{W}} / \mathrm{S} \mathrm{l}=0.16\right)$, in contrast to all other stereospondylomorphs. 


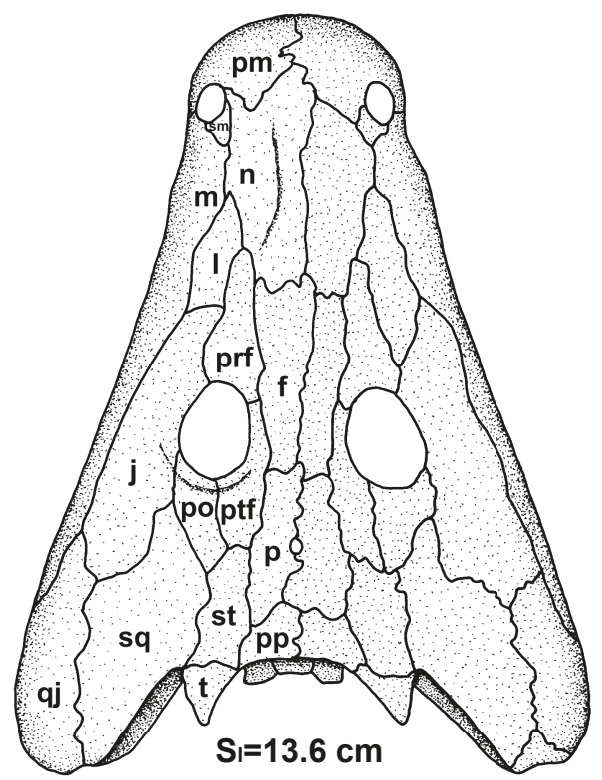

a Glanochthon angusta

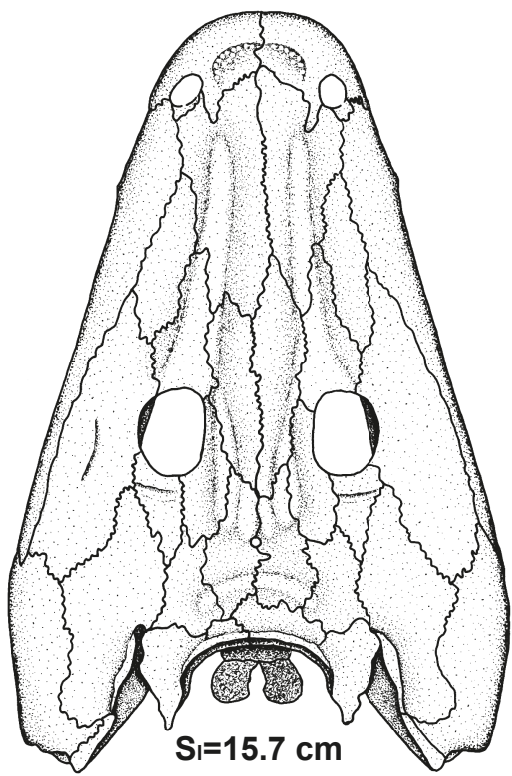
b Korkonterpeton kalnense gen. et sp. nov.

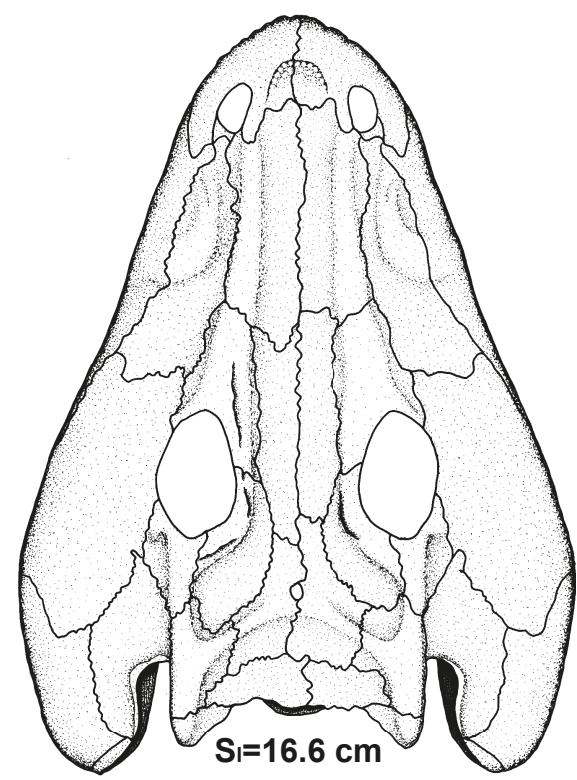

C Intasuchus silvicola
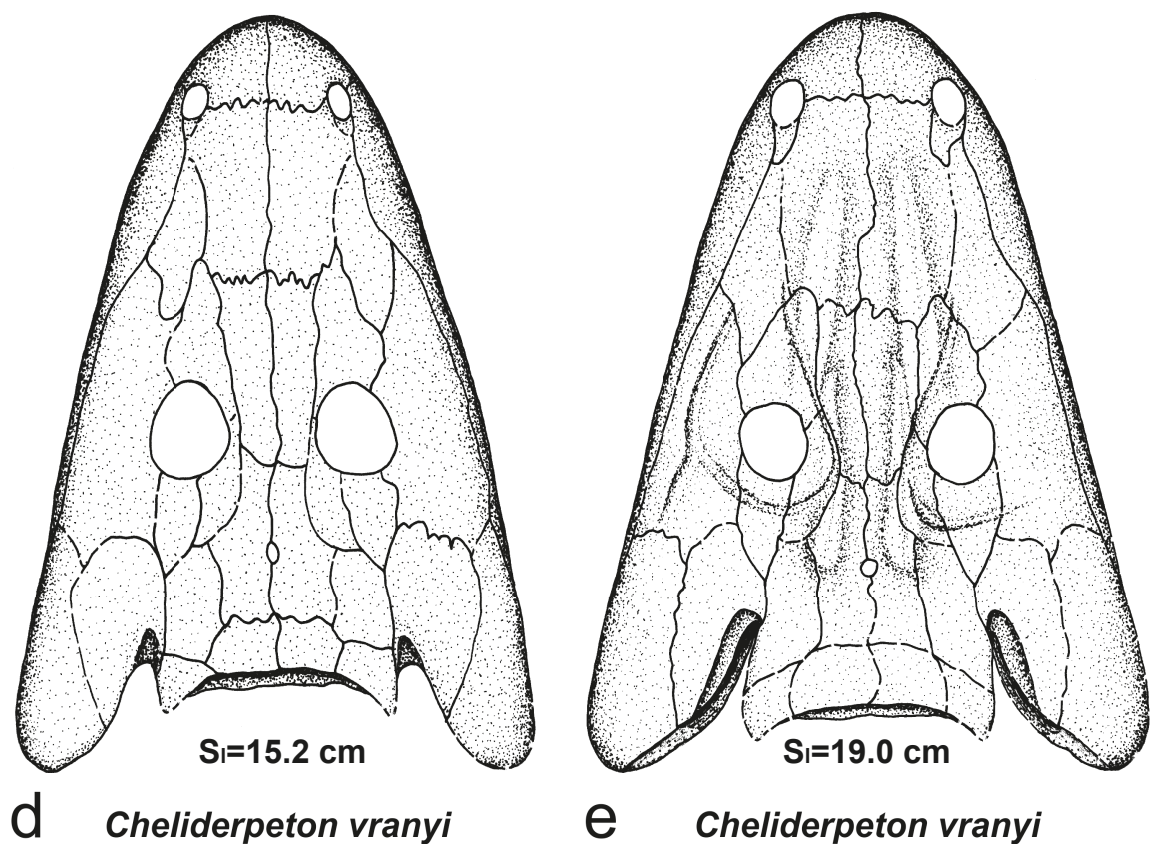

Text-fig. 14. Comparison of dorsal skull roof reconstructions from related stereospondylomorph amphibians. a: after Schoch and Witzman 2009b, b: holotype MEBHK - P 82447, c - holotype PIN 570/1, d, e: after Werneburg and Steyer 2002. Abbreviations: f - frontal, j - jugal, l - lacrimal, $\mathbf{m}$ - maxilla, n - nasal, p - parietal, pm - premaxilla, po - postorbital, pp - postparietal, prf - prefrontal, ptf - postfrontal, ptr - postorbital-tabular ridge, qj - quadratojugal, sm - septomaxilla, sq - squamosal, st supratemporal, $\mathrm{t}$ - tabular. Sl - midline skull length.

Therefore, the maximal width of the skull is at the level of the pineal foramen and the anterior part of the quadratojugal $\left(\mathrm{mS}_{\mathrm{w}}=0.73\right)$, as in Korkonterpeton kalnense gen. et sp. nov. At this level, the posterolateral region of the jugal and the anterolateral region of the quadratojugal are missing, but it is possible to reconstruct the width of the skull according to the well-preserved palatal bones (Text-fig. 12b): the posteriormost margin of the skull probably runs medially to the posterolateral region of the quadratojugal. The posterior margin of the quadratojugal and the quadrate are not preserved. The squamosal is posteriorly narrow and does not extend posteriorly further than the posterior region of the tabular (in contrast to Glanochthon). The 'otic notch' (squamosal embayment) is very deep and wide. The short suture between the squamosal and the supratemporal starts posteriorly at midlength of the supratemporal (in contrast to Glanochthon and Korkonterpeton kalnense gen. et sp. nov., but similar in the late adult C. vranyi). The jaw joints are clearly posterior to the occiput. The parietal and supratemporal are relatively short and wide, in contrast to all other stereospondylomorphs. The anterolateral region of the parietal and the anteromedial region of the supratemporal present embayments for the large posterior region of the postfrontal. The tabular is very short, in contrast to 
Korkonterpeton kalnense gen. et sp. nov. The suture between the tabular and supratemporal lies at the same level as the occipital margin of the skull, as in G. angusta. The postparietal is elongated (in contrast to Korkonterpeton kalnense gen. et sp. nov.) and laterally expanded in an embayment of the posteromedian part of the supratemporal (in contrast to all other stereospondylomorphs). The posterior skull margin is slightly concave because of the short distance between the posterior extremity of the tabular corner and the occipital midline margin $(\mathrm{Th} 1 / \mathrm{S} 1=0.06$; as in $C$. vranyi $)$.

The natural relief of the dorsal skull roof is very well preserved (Text-figs 12a, c, 13a) and shows several ridges: the longitudinal ridge (prr) starts just below the posterior part of the alary process of the premaxilla, and runs along the anterior orbital margin of the prefrontal where it becomes progressively wider. It continues around the medial orbital margin of the pre- and postfrontal and becomes the intraorbital ridge (ior) up to the anterolateral end of the postorbital. The postorbital-tabular ridge (ptr) runs from the postorbital along the lateral margin of the supratemporal up to the tabular horn. At mid-length of the supratemporal, it becomes the parietalsupratemporal ridge (psr) which runs to the pineal foramen. Additionally, a curved lacrimal ridge (lr) lies on the anterior part of the lacrimal. This pattern of dorsal ridges looks similar to that of the eryopids but here it is less complex, especially on the postorbital region (Sawin 1941, Werneburg 2007: figs 2a, 6, 7). A few transverse ridges between the longitudinal ridges are also missing on the preorbital region of Intasuchus and stereospondylomorphs in general. In eryopids, the lacrimal ridge runs more longitudinally and diagonally across the whole lacrimal. An elongated longitudinal ridge from the nasal up to the tabular (without transverse ridges) is known in Glanochthon latirostris (Schoch and Witzmann 2009b: fig. 4B), Archegosaurus decheni (Witzmann 2006: figs 4a, 5a) and the archegosaur Collidosuchus tchudinovi (Gubin 1991: fig. 1a).

Lateral line sulci are only impressed on the pre- and postfrontals. They are part of the supraorbital sulcus which is deeply marked.

Palate (Text-figs 12b, d, 13b, 15). Most of the palatal bones are preserved as well as the dentition. The premaxilla bears ten teeth; the first three and the last two are small, but numbers 5-8 are almost as large as the palatine fangs. The maxillary bears about 25 teeth; the anterior ones are middlesized and the posterior ones smaller. No maxillary teeth are enlarged. The ventral side of the maxilla is medially enlarged next to the choana, which is similar to that of Korkonterpeton kalnense gen. et sp. nov.

The vomer is narrow and elongated. A diagonally arranged pair of fangs, the size of the premaxillar middlesized teeth, is visible near the anteromedian margin of the choana. This correlates with the ventral premaxilla-maxilla suture in the posterior end of the choana. These two last characters are also seen in the other stereospondylomorphs but not in Korkonterpeton kalnense gen. et sp. nov. The vomer and the pterygoid are covered with numerous small denticles. The concave posterior margin of both vomers borders a very narrow part of the interpterygoid vacuities. In Intasuchus, the posterior process of the vomer is not developed, contra many other stereospondylomorphs. It is not clear if the anterior palatal depressions are present. A parachoanal vomerine tooth row is located on an elevation parallel to the medial choana: it contains five teeth the same size as the small premaxillary and maxillary teeth and small denticles anteriorly. A parachoanal vomerine tooth row is missing in Sclerocephalus, Glanochthon and Korkonterpeton kalnense gen. et sp. nov., but well known in Archegosaurus decheni (Witzmann 2006).

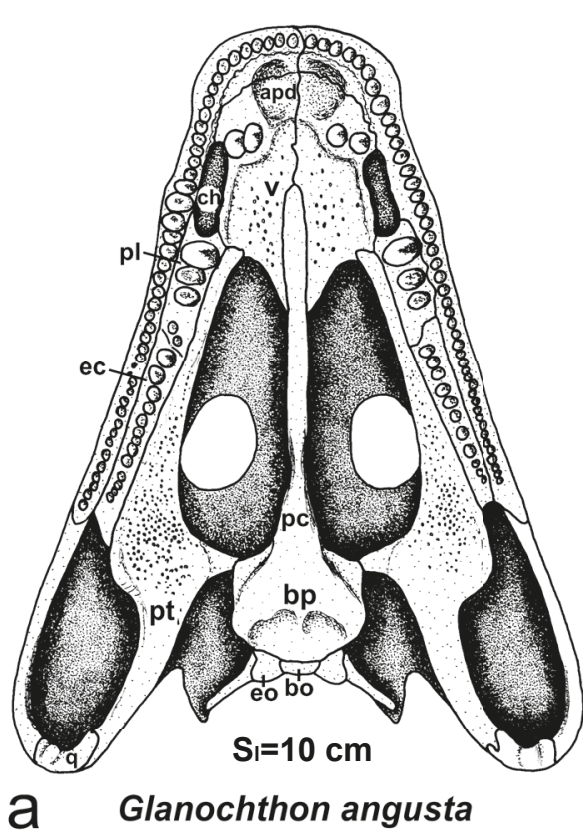

Text-fig. 15. Comparison of ventral palatal skull reconstructions from related stereospondylomorph amphibians. a: after Schoch and Witzman 2009b, b: holotype MEBHK - P 82447, c: holotype PIN 570/1. Abbreviations: apd - anterior palatal depression, bo - basioccipital, bp - basal plate of parasphenoid, ch - choane, ec - ectopterygoid, eo - exoccipital, pc - cultriform process of parasphenoid, pl - palatine, ps - parasphenoid, pt - pterygoid, q - quadrate, v - vomer. S I - midline skull length. 
The choana is very narrow and elongated. The length of this slit-like opening is twice that of the nostril, as is the case in several stereospondylomorphs but not in Sclerocephalus where it is wider, and not in Archegosaurus where it is longer.

The ectopterygoid, of similar length as the palatine, reaches posteriorly the level of the anterior half of the orbit. In all other sterospondylomorphs this bone is longer and clearly extends posteriorly behind the orbit. The ectopterygoid has 8-9 teeth. The first and probably second (missing) teeth are large fangs the same size as the largest premaxillary teeth, only the palatine fangs are larger. The other posterior teeth on the ectopterygoid are small, but larger than the laterally neighbouring posterior maxillary teeth. The shape and dentition of the ectopterygoid is more similar to that of Sclerocephalus than to Glanochthon or Korkonterpeton kalnense gen. et sp. nov.

The palatine is more elongated than the choana and has space for 4 very large teeth. It bears two pairs of fangs which are the largest teeth in the skull. The palatine dentition is comparable with that of Glanochthon, but differs from Korkonterpeton kalnense gen. et sp. nov.

The pterygoid may have a very elongated basipterygoid ramus in contrast to all other stereospondylomorphs. This elongation of the basipterygoid ramus is putative, it is based on the median suture of the skull between the vomers in an approximately natural position to the maxillary tooth arcade as an indication of the natural margin of the skull. The quadrate ramus is only partly preserved. The palatine ramus is curved medially and has a broad anterior part, which reaches about two-thirds of the vomer width (in contrast to Glanochthon, but similar in Sclerocephalus and Korkonterpeton kalnense gen. et sp. nov.). The suture between the vomer and the pterygoid is very elongated. The anterolateral palatine ramus clearly ends posteriorly to the choana (in contrast to Korkonterpeton kalnense gen. et sp. nov., but known from Glanochthon).

The parasphenoid has a narrow basal plate. The probably narrow cultriform process only contacts the posteromedian part of the vomer (i.e., no embayment of the vomer is visible). Both characters contrast with Korkonterpeton kalnense gen. et sp. nov., Glanochthon and Sclerocephalus. The anterior tip of the cultriform process reaches the level of the anterior pterygoid posteriorly to the choana, in contrast to Sclerocephalus, Glanochthon and Korkonterpeton kalnense gen. et sp. nov. The large basipterygoid process of the basal plate is anterolaterally directed and long sutured with the basipterygoid process of the pterygoid (similar in Korkonterpeton kalnense gen. et sp. nov., but different in Glanochthon and Sclerocephalus). A fine groove for the carotid artery runs almost parallel to the medial margin of the basipterygoid process of the basal plate. The basal plate has an oval elevated patch covered by a denticle field between the basipterygoid processes. The narrow shape of the basal plate together with the denticle field is known from Archegosaurus decheni (Witzmann 2006) and the archegosaurid Platyoposaurus stuckenbergi (Konzhukova 1955). The dorsal region of the basal part of the cultriform process appears through the left orbit in the specimen as preserved (Text-figs 12a, 13a). The fossa hypophysialis and three foramina are visible. The pair of outstanding ones may be for the anterior arteria carotis cerebralis (compare Gubin 1991: figs 13, 14).

The interpterygoid vacuity is posterolaterally very wide (in contrast to all stereospondylomorphs). The subtemporal fenestra is relatively narrow and anteriorly elongated (compare with the length of the ectopterygoid).

Braincase (Text-figs 12b, d, 13b). The ventral basioccipital is sutured anteriorly with the basal plate of the parasphenoid. The exoccipital and quadrate are not preserved.

Visceral skeleton (Text-figs 12b, 13b). The stapes has a wide footplate and a short preserved, slender shaft. The quadrate process is not visible. The basibranchial is not preserved.

\section{Remarks on stereospondylomorph relationships}

Even if the aim of this article is to provide a full description of Korkonterpeton kalnense gen. et sp. nov. and a redescription of Intasuchus silvicola, not a complete phylogeny of the stereospondylomorphs which is out of the scope of this work, some remarks on previous conclusions regarding the stereospondylomorph relationships are given here:

Eltink et al. (2019), in their extensive phylogenetic analysis of stereospondylomorphs, put Intasuchus silvicola and Cheliderpeton vranyi in the family Intasuchidae on the basis of three apparent shared characters: presence of sensory line canals on the nasal and lacrimal, frontal shorter than nasal, and absence of a triangular posterior process on the premaxilla. However, Intasuchus silvicola and Cheliderpeton vranyi do not have sensory line canals on the nasal and lacrimal, and only the largest specimens show a frontal shorter than a nasal - an ontogenetically influenced character which is also present in other stereospondylomorphs such as Korkonterpeton kalnense gen. et sp. nov. or Cheliderpeton vranyi (see Text-fig. 14 for comparison). Moreover, a triangular posterior process of the premaxilla is clearly present in Intasuchus silvicola. Consequently, the characters used by Eltink et al. (2019) to define their 'Intasuchidae' are considered here as artifactual because they are not shared by these taxa. In their phylogeny, Eltink et al. (2019) put also Glanochthon latirostris in the family Sclerocephalidae: we agree with most of their synapomorhies but we also observed them in other taxa (Memonomenos, Cheliderpeton, and few eryopoid genera too). The absence of the ossified basioccipital may be ontogenetically influenced.

Concerning the phylogeny of Schoch and Witzmann (2009b), we preliminary included Korkonterpeton kalnense gen. et sp. nov. in their matrix and corrected the coding of Intasuchus silvicola following our redescription, but we obtained a global polytomy for all the considered stereospondylomorphs. It seems therefore that the relationships of these taxa involved many homoplasies and they still need works to be completely solved.

Interestingly, the first stereospondylomorph temnospondyls are only known in the early Permian of western and central Europe so far: together with Korkonterpeton kalnense gen. et sp. nov., they are Cheliderpeton vranyi and Sclerocephalus stambergi (Klembara and Steyer 2012) from Czechia as well as S. haueseri (Boy 1993), S. bavaricus 


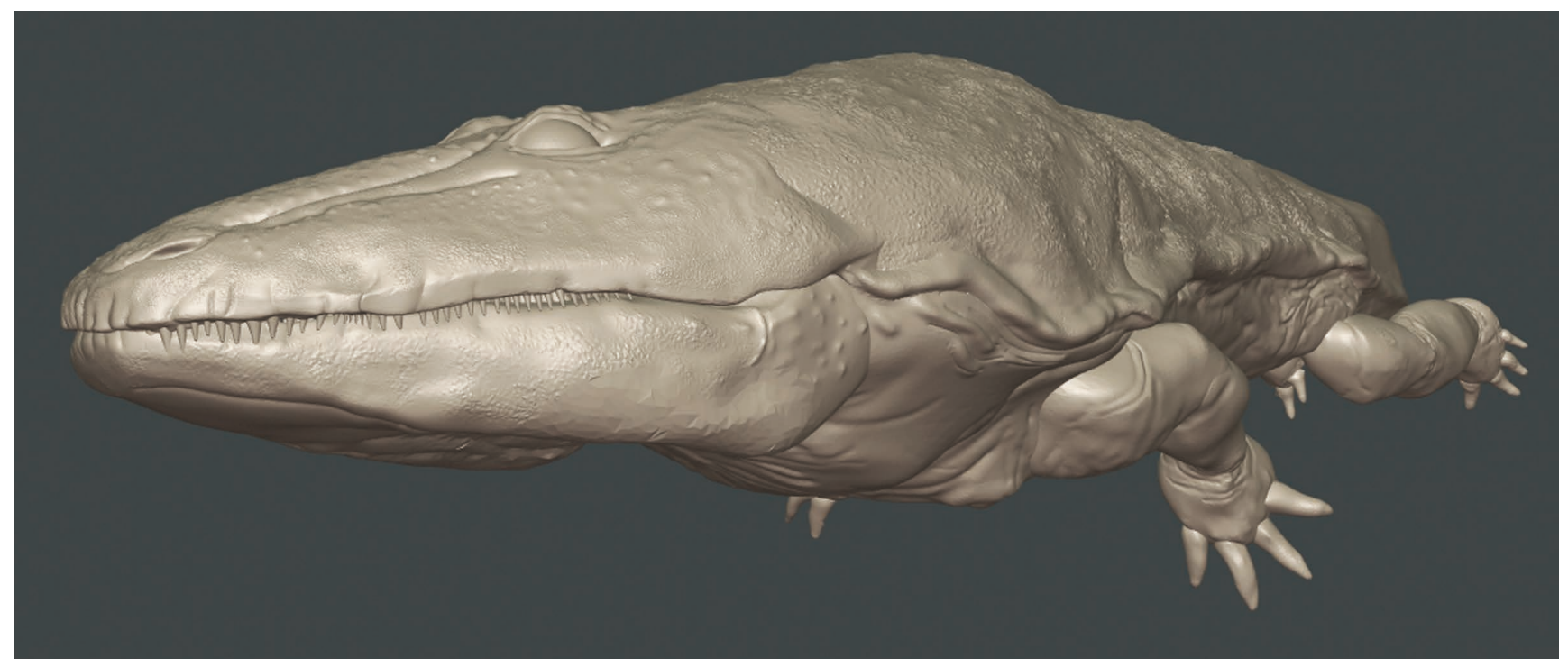

Text-fig. 16. Life reconstruction of the new stereospondylomorph amphibian Korkonterpeton kalnense gen. et sp. nov. from the Permian of Czechia (artwork by Jalil Simon, France).

(Boy 1993), S. jogischneideri (Werneburg 1992), S. nobilis (Schoch and Witzmann 2009a), Glanochthon angusta and G. latirostris (Schoch and Witzmann 2009b) from Germany. A Cheliderpeton-like genus has also been mentioned in the Permian of France (Steyer et al. 2000). Compared with other stereospondylomorphs such as Archegosaurus (Witzmann 2006) from Germany and Memonomenos (Milner 1978) from Czechia, all these taxa are considered as stemstereospondylomorphs in most of the phylogenies (e.g., Schoch and Witzmann 2009a, b, Klembara and Steyer 2012, Eltink et al. 2019).

This apparent restricted occurrence of the stemstereospondylomorphs within European intramountaneous basins may be linked with their mainly aquatic lifestyle that could reduce their migration capacity. Yet their apparent increasing number during the earliest Permian (Asselian) may be linked with the apparent decreasing number of sharks (excl. orthacanthids) as possible predators from the same palaeolake deposits. These conditions may have favoured the radiation of the early stereospondylomorphs during the early Permian. The group may originate in the Carboniferous, but the Carboniferous paleolake deposits are rarer and less investigated.

\section{Conclusions}

Korkonterpeton kalnense gen. et sp. nov. is described on the basis of an exquisite nearly complete specimen from the lower Permian of the Krkonoše Piedmont Basin, Czechia. The outline and the shape of the skull are very distinct in stereospondylomorphs. The new genus Korkonterpeton is characterized by a unique combination of the following characters: a relatively wide premaxillary region, boxlike and blunt; a straight lateral maxillary margin; a medially curved posterolateral margin of the skull; and a maximal skull width at the level of the anterior region of the quadratojugal. Additionally, this new genus is also characterized by vomerine fangs located anteriorly to the choana, extraordinary elongated exoccipitals and anteriorly widened pterygoids. The unique characters defining the new species Korkonterpeton kalnense are: length of the tabular much greater than the width, tabular length as long as the supratemporal; a very short postparietal, only half the length of that in related stereospondylomorphs; a concave posterior margin of the quadratojugal and dorsomedial part of the quadrate with a steplike shelf region; a slightly swollen parasphenoid cultriform process reaching the anterior level of the orbit, and with an anterior third embedded in the posteromedian region of the vomer; well ossified sphenethmoid and epipterygoid; and a ventrally large hookshaped quadrate.

The genera Cheliderpeton and Glanochthon share a number of characters with Korkonterpeton: a narrow jugal, a very short basipterygoid ramus on the pterygoid, an ectopterygoid twice the length of the palatine, and an ectopterygoid tooth arcade with identical sized teeth (without a separated tusk pair). They may belong to single family we have to test in the future.

To investigate these stereospondylomorph relationships, it was also necessary to revise Intasuchus silvicola, which was therefore redescribed here for the first time. This taxon shows drastic differences compared to Cheliderpeton, Glanochthon and Korkonterpeton: this suggests that the Russian Intasuchus silvicola belongs to its proper family Intasuchidae KonzhuKova, 1956.

A complete phylogeny of the stereospondylomorph temnospondyls will allow to precise the relationships of Korkonterpeton and Intasuchus with their relatives, but this is out of the scope of this article which aimed to firstly provide a precise anatomical description of Korkonterpeton kalnense gen. et sp. nov. and secondly a redescription of Intasuchus silvicola.

\section{Acknowledgements}

This research was supported by an internal research project of the Museum of Eastern Bohemia in Hradec Králové, the CNRS Paris and the Museum of Natural 
History Schleusingen. RW thanks the Deutsche Forschungsgemeinschaft (DFG) who financially supported this research with the grant DFG-We 2833/4-1, Yuri Gubin (†) and Igor Novikov (PIN, Moscow) for their help concerning Intasuchus. We acknowledge Jalil Simon (France) for his artistic reconstruction of Korkonterpeton kalnense gen. et sp. nov. visible in Text-fig. 16. We also thank the reviewers Josep Fortuny (Barcelona) and Jozef Klembara (Bratislava) for their constructive comments.

\section{References}

Blecha, M., Martínek, K., Drábková, J., Šimůnek, Z., Zajíc, J. (1997): Environmental changes at the Carboniferous/ Permian boundary and their impact on floral and faunal assemblages of the fossiliferous lacustrine horizons of the Krkonoše Piedmont Basin; Project Final Report. MS, project GAČR 205/94/0692, Czech Geological Survey, Prague, the Czech Republic. (copy in library of Museum of Eastern Bohemia in Hradec Králové, the Czech Republic)

Blecha, M., Martínek, K., Mihaljevič, M. (1999): Paleoenvironmental changes of the semipermanent Kalná Lake (Lower Permian), Krkonoše Piedmont Basin, Czech Republic: sedimentary and geochemical record. - Acta Universitatis Carolinae, Geologica, 43(4): 657-665.

Boy, J. A. (1988): Über einige Vertreter Eryopoidea (Amphibia: Temnospondyli) aus dem europäischen Rotliegend (?höchstes Karbon-Perm) 1. Sclerocephalus. - Paläontologische Zeitschrift, 62: 107-132. https://doi.org/10.1007/BF02989838

Boy, J. A. (1990): Über einige Vertreter der Eryopoidea (Amphibia: Temnospondyli) aus dem europäischen Rotliegend (?höchstes Karbon-Perm). 3. Onchiodon.Paläontologische Zeitschrift, 64: 287-312. https://doi.org/10.1007/BF02985720

Boy, J. A. (1993): Über einige Vertreter der Eryopoidea (Amphibia: Temnospondyli) aus dem europäischen Rotliegend (?höchstes Karbon-Perm). 4. Cheliderpeton latirostre. - Paläontologische Zeitschrift, 67: 123-143. https://doi.org/10.1007/BF02985874

Eltink, E., Schoch, R. R., Langer, M. C. (2019): Interrelationships, palaeobiogeography and early evolution of Stereospondylomorpha (Tetrapoda: Temnospondyli). Journal of Iberian Geology, 45(2): 251-267. https://doi.org/10.1007/s41513-019-00105-z

Fortuny, J., Marcé-Nogué, J., Steyer, J.-S., de Esteban-Trivigno, S., Mujal, E., Gil, L. (2016): Comparative 3D analyses and palaeoecology of giant early amphibians (Temnospondyli: Stereospondyli). - Scientific Reports 6: 30387 (10 pp.). https://doi.org/10.1038/srep30387

Frič, A. (1877): Über einen neuen Saurier aus den Kalksteinen der Permformation (U. Dyas) aus Braunau in Böhmen. - Verlag der königlich-böhmischen Gesellschaft der Wissenschaften, Prag, 3 pp.

Fritsch, A. (1879): Fauna der Gaskohle und der Kalksteine der Permformation Böhmens, 1(1). - Selbstverlag (in Commission bei Fr. Řivnáč), Prag, 92 pp.

https://doi.org/10.5962/bhl.title. 14775
Fritsch, A. (1895): Fauna der Gaskohle und der Kalksteine der Permformation Böhmens, 3(4). - Selbstverlag (in Commission bei Fr. Řivnáč), Prag, 132 pp.

Goldfuss, G. A. (1847): Beiträge zur vorweltlichen Fauna des Steinkohlengebirges. - Naturhistorischer Verein für die preussischen Rheinlande (in Commission bei Henry \& Cohen), Bonn, [4] $+26+[2]$ pp. +5 pls.

Gubin, Y. M. (1983): Pervye eriopidy iz permi Vostochno-Evropeyskoy platformy [The First Eryopids from the Permian of the East European Platform]. - Paleontologicheskiy zhurnal, 1983(4): 110-115. (in Russian)

Gubin, Y. M. (1984): O sistematicheskom polozhenii intazukhid[On the systematic position of the intasuchids].-Paleontologicheskiy zhurnal, 1984(2): 118-120. (in Russian)

Gubin, Y. M. (1991): Permskie arkhegozavroidnyi amfibii SSSR [Permian archegosauroid amphibians from the USSR]. - Trudy Paleontologicheskogo Instituta Akademii Nauk SSSR, 249: 1-138. (in Russian)

Gubin, Y. M. (1997): Skull morphology of Archegosaurus decheni Goldfuss (Amphibia, Temnospondyli) from the Early Permian of Germany. - Alcheringa, 21: 103-121. https://doi.org/10.1080/03115519708619178

Klembara, J., Steyer, J. S. (2012): A new species of Sclerocephalus (Temnospondyli: Stereospondylomorpha) from the Early Permian of the Boskovice Basin (Czech Republic). - Journal of Paleontology, 86(2): 302-310. https://doi.org/10.1666/11-051.1

Konzhukova, E. D. (1953): Nizhnepermskaya fauna nazemnykh pozvonochnykh Severnogo Priural'ya (basseyn r. Inty) [Fauna of vertebrates from Upper Permian of northern Priural region (basin of river Inta)]. - Doklady Akademii Nauk SSSR, 89(4): 723-726. (in Russian)

Konzhukova, E. D. (1955): Permskkie i triasovye labirintodonty Povolzh'ya i Priural'ya [Permian and Triassic labyrinthodonts of the Volga River basin and Ural regions]. - Trudy Paleontologicheskogo Instituta Akademii Nauk SSSR, 49: 89-157. (in Russian)

Konzhukova, E. D. (1956): Intinskaya fauna nizhney permi Severnogo Priural'ya [The Intan Lower Permian fauna of the northern Ural region]. - Trudy Paleontologicheskogo Instituta Akademii Nauk SSSR, 62: 5-50. (in Russian)

Martínek, K., Blecha, M., Daněk, V., Franců, J., Hladíková, J., Johnová, R., Uličný, D. (2006): Record of palaeoenvironmental changes in a Lower Permian organic-rich lacustrine succession: Integrated sedimentological and geochemical study of the Rudník member, Krkonoše Piedmont Basin, Czech Republic. - Palaeogeography, Palaeoclimatology, Palaeoecology, 230: 85-128. https://doi.org/10.1016/j.palaeo.2005.07.009

Milner, A. R. (1978): A reappraisal of the early Permian amphibians Memonomenos dyscriton and Cricotillus brachydens. - Palaeontology, 21(3): 667-686.

Moulton, J. M. (1974): A description of the vertebral column of Eryops based on the notes and drawings of A. S. Romer. - Breviora, 428: 1-44.

Opluštil, S., Schmitz, M., Kachlík, V., Štamberg, S. (2016): Re-assessment of lithostrastigraphy, biostratigraphy, and volcanic activity of the Late Paleozoic IntraSudetic, Krkonoše-Piedmont and Mnichovo Hradiště basins (Czech Republic) based on new U-Pb CA-ID- 
TIMS ages. - Bulletin of Geosciences, 91(2): 399-432. https://doi.org/10.3140/bull.geosci.1603

Prouza, V., Tásler, R. (2001): Podkrkonošská pánev [Krkonoše Piedmont Basin]. - In: Pešek, J. et al., Geologie a ložiska svrchnopaleozoických limnických pánví České republiky [Geology and deposits of Late Paleozoic limnic basins of the Czech Republic]. Český Geologický ústav, Praha, pp. 128-166. (in Czech)

Romer, A. S. (1952): Late Pennsylvanian and Early Permian vertebrates in the Pittsburgh-West Virginia region. Annals of Carnegie Museum, 33: 47-113.

Ruta, M., Benton, M. J. (2008): Calibrated diversity, tree topology and the mother of mass extinctions: the lesson of temnospondyls. - Palaeontology, 51(6): 1261-1288. https://doi.org/10.1111/j.1475-4983.2008.00808.x

Sawin, H. J. (1941): The cranial anatomy of Eryops megacephalus. - Bulletin of the Museum of Comparative Zoology, Harvard College, 88: 405-464.

Schneider, J. W., Lucas, S. G., Scholze, F., Voigt, S., Marchetti, L., Klein, H., Opluštil, S., Werneburg, R., Golubev, V. K., Barrick, J. E., Nemyrovska, T., Ronchi, A., Day, M. O., Silantiev, V. V., Rößler, R., Saber, H., Linnemann, U., Zarinova, V., Shen, S. (2020): Late Paleozoicearly Mesozoic continental biostratigraphy - Links to the Standard Global Chronostratigraphic Scale. - Paleoworld, 29(2): 186-238.

https://doi.org/10.1016/j.palwor.2019.09.001

Schneider, J., Werneburg, R. (2012): Biostratigraphie des Rotliegend mit Insekten und Amphibien. - In: Deutsche Stratigraphische Kommission (ed.), Stratigraphie von Deutschland X. Rotliegend. Teil I: Innervariscische Becken. Schriftenreihe der Deutschen Gesellschaft für Geowissenschaften, 61: 110-142.

Schoch, R. R., Milner, A. R. (2000): Stereospondyli, StemStereospondyli, Rhinesuchidae, Rhitidostea, Trematosauroidea, Capitosauroidea (Handbuch der Paläoherpetologie / Encyclopdia of Paleoherpetology, Part 3B). Verlag Dr. Friedrich Pfeil, München, xii + 220 pp.

Schoch, R. R., Witzmann, F. (2009a): Osteology and relationships of the temnospondyl genus Sclerocephalus. - Zoological Journal of the Linnean Society, 157: 135-168. https://doi.org/10.1111/j.1096-3642.2009.00535.x

Schoch, R. R., Witzmann, F. (2009b): The temnospondyl Glanochthon from the Lower Permian Meisenheim Formation of Germany. - Special Papers in Palaeontology, 81: $121-136$.

Steyer, J. S. (2000a): Are European Paleozoic Amphibians good stratigraphical markers? - Bulletin de la Société Géologique de France, 171(1): 127-135.

Steyer, J. S. (2000b): Ontogeny and phylogeny of temnospondyls: a new method of analysis. - Zoological Journal of the Linnean Society, 130: 449-467.

https://doi.org/10.1111/j.1096-3642.2000.tb01637.x

Steyer, J. S. (2004): Phylogenetic or stratophenetic systematics? (A comment of Werneburg, R. 2003: The branchiosaurid amphibians from the Lower Permian of Buxi-èresles-Mines, Bourbon l'Archambault Basin (Allier, France) and their biostratigraphic significance. Bulletin de la Société Géologique de France, 174(4): 343-349). - Bulletin de la Société Géologique de France, 175(4): 423-425. https://doi.org/10.2113/174.4.343
Steyer, J. S., Escuillié, F., Pouillon, J.-M., Broutin, J., Debriette, P., Freytet, P., Gand, G., Poplin, C., Rage, J.-C., Rival, J., Schneider, J. W., Stamberg, S., Werneburg, R., Cuny, G. (2000): New data on the flora and fauna from the ?uppermost Carboniferous-Lower Permian of Buxières-les-Mines, Bourbon 1'Archambault Basin (Allier, France). A preliminary report. - Bulletin de la Société Géologique de France, 171(2): 239-249.

https://doi.org/10.2113/171.2.239

Steen, M. C. (1938): On the fossil Amphibia from the Gas Coal of Nýrrany and other deposits in Czechoslovakia. Proceedings of the Zoological Society of London, Ser. B, 108(2): 205-283. https://doi.org/10.1111/j.1096-3642.1938.tb00027.x

Štamberg, S. (2012): Permské aktinopterygijní ryby a jejich využití pro paralelizaci výchozů významných fosiliferních obzorů podkrkonošské pánve [Permian actinopterygian fishes and their use to correlate outcrops of the significant fossiliferous horizons of the Krkonoše Piedmont Basin]. - Zprávy o geologických výzkumech, 45: 149-150. (in Czech with english Abstract)

Štamberg, S. (2014a): Fossiliferous Early Permian horizons of the Krkonoše Piedmont Basin and Boskovice Graben (Bohemian Massif) in view of the occurrence of actinopterygians. - Paläontologie, Stratigraphie, Fazies (22), Freiberger Forschungshefte, C, 548: 45-60.

Štamberg, S. (2014b): Nález kosterních fragmentů velkého obojživelníka a další permské fauny z lokalty Arnultovice $\mathrm{v}$ podkrkonošské pánvi [Discovery of skeletal fragment of a large amphibian and other Permian fauna from locality Arnultovice in the Krkonoše Piedmont Basin]. - Zprávy o geologických výzkumech, 47: 94-97. (in Czech with english Abstract)

Werneburg, R. (1992): Sclerocephalus jogischneideri n. sp. (Eryopoidea, Amphibia) aus dem Unterrotliegenden (Unterperm) des Thüringer Waldes. - Freiberger Forschungshaft, C, 445: 29-48.

Werneburg, R. (2007): Der "Manebacher Saurier" - neuer großer Eryopide (Onchiodon) aus dem Rotliegend (Unter-Perm) des Thüringer Waldes. - Veröffentlichungen Naturhistorisches Museum Schleusingen, 22: 3-40.

Werneburg, R., Berman, D. S. (2012): Revision of the aquatic eryopid temnospondyl Glaukerpeton avinoffi Romer, 1952, from the Upper Pennsylvanian of North America. - Annals of Carnegie Museum, 81: 33-60. https://doi.org/10.2992/007.081.0103

Werneburg, R., Lucas, S. G., Schneider, J. W., Rinehart, L. F. (2010): First Pennsylvanian Eryops (Temnospondyli) and its Permian record from New Mexico. - New Mexico Museum of Natural History and Science Bulletin, 49: 129-135.

Werneburg, R., Schneider, J. W. (1996): The Permian Temnospondyl Amphibians of India. - Special Papers in Palaeontology, 52: 105-128.

Werneburg, R., Schneider, J. W. (2004): Stratophenetic approach? An answer to J. S. Steyer, 2004: Phylogenetic or stratophenetic systematics? - Bulletin de la Société Géologique de France, 175 (4): 425. https://doi.org/10.2113/175.4.425

Werneburg, R., Schneider, J. W. (2006): Amphibian biostratigraphy of the European Permo-Carboniferous. - 
In: Lucas, S. G., Cassinis, G., Schneider, J. W. (eds), Non-marine Permian biostratigraphy and biochronology. Special Publications, Geological Society, London, 265: 201-215.

https://doi.org/10.1144/GSL.SP.2006.265.01.09

Werneburg, R., Steyer, J. S. (2002): Revision of Cheliderpeton vranyi Fritsch, 1877 (Amphibia, Temnospondyli) from the Lower Permian of Bohemia (Czech Republic). - Paläontologische Zeitschrift, 76(1): 142-162. https://doi.org/10.1007/BF02988193

Witzmann, F. (2006): Cranial anatomy and ontogeny of the Permo-Carboniferous temnospondyl Archegosaurus decheni from the Saar-Nahe Basin, Germany. - Earth and Environmental Science Transactions of The Royal Society of Edinburgh, 96(for 2005): 131-162.
Witzmann, F., Schoch, R. R. (2006): The postcranium of Archegosaurus decheni, and a phylogenetic analysis of temnospondyl postcrania. - Palaeontology, 49: 1211-1235. https://doi.org/10.1111/j.1475-4983.2006.00593.x

Yates, A. M., Warren, A. A. (2000): The phylogeny of the 'higher' temnospondyls (Vertebrata: Choanata) and its implications for the monophyly and origins of the Stereospondyli. - Zoological Journal of the Linnean Society, 128(1): 77-121.

https://doi.org/10.1111/j.1096-3642.2000.tb00650.x

Zittel, K. (1887-1890): Handbuch der Paläontologie. 1. Abtheilung: Paläozoologie. III. Band: Vertebrata (Pisces, Amphibia, Reptilia, Aves). - R. Oldenbourg, München, Leipzig, 900 pp. [2. Lieferung, including pages 257-436, was published in 1888] 